\title{
Karyotypes of central European spiders of the genera Arctosa, Tricca, and Xerolycosa (Araneae: Lycosidae)
}

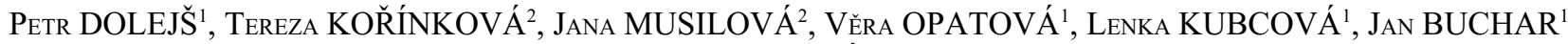 \\ and JiǨí KRÁL ${ }^{2}$
}

\begin{abstract}
${ }^{1}$ Department of Zoology, Charles University in Prague, Faculty of Science, Vini čná 7, CZ - 12844 Prague 2, Czech Republic, e-mails: dolejs@natur.cuni.cz; vera.opatova@seznam.cz; lenka.kubcova@centrum.cz; lucie.jurickova@seznam.cz

${ }^{2}$ Laboratory of Arachnid Cytogenetics, Department of Genetics and Microbiology, Charles University in Prague, Faculty of Science, Viničná 5, CZ - 12844 Prague 2, Czech Republic, e-mails: korinko1@natur.cuni.cz; jana-musilova@seznam.cz; spider@natur.cuni.cz
\end{abstract}

Key words. Lycosidae, spiders, karyotype, sex chromosomes, meiosis, constitutive heterochromatin, nucleolar organizer region, Czech Republic, Austria

\begin{abstract}
The aim of this study was to characterize karyotypes of central European spiders of the genera Arctosa, Tricca, and Xerolycosa (Lycosidae) with respect to the diploid chromosome number, chromosome morphology, and sex chromosomes. Karyotype data are reported for eleven species, six of them for the first time. For selected species the pattern in the distributions of the constitutive heterochromatin and the nucleolar organizer regions (NORs) was determined. The silver staining technique for detecting NORs of lycosid spiders was standardized. The male karyotype consisted of $2 \mathrm{n}=28$ (Arctosa and Tricca) or $2 \mathrm{n}=22$ (Xerolycosa) acrocentric chromosomes. The sex chromosome system was $\mathrm{X}_{1} \mathrm{X}_{2} 0$ in all species. The sex chromosomes of T. lutetiana and X. nemoralis showed unusual behaviour during late diplotene, namely temporary extension due to decondensation. C-banding technique revealed a small amount of constitutive heterochromatin at the centromeric region of the chromosomes. Two pairs of autosomes bore terminal NORs. Differences in karyotypes among Arctosa species indicate that the evolution of the karyotype in this genus involved autosome translocations and size changes in the sex chromosomes. Based on published results and those recorded in this study it is suggested that the ancestral male karyotype of the superfamily Lycosoidea consisted of 28 acrocentric chromosomes.
\end{abstract}

\section{INTRODUCTION}

The family Lycosidae (wolf spiders) belongs to the superfamily Lycosoidea that is included in the entelegyne lineage of araneomorph spiders (Jocqué \& DippenaarSchoeman, 2007). The lycosids occur all over the world and are very diverse with 2367 species in 116 genera described so far (Platnick, 2010). The present study concentrated on three lycosid genera, namely Arctosa C.L. Koch, 1847, Tricca Simon, 1889, and Xerolycosa Dahl, 1908. Eight species and one subspecies of the genus Arctosa, one species of the genus Tricca, and two species of the genus Xerolycosa occur in central Europe (Blick et al., 2004). All were included in this study except $A$. stigmosa (Thorell, 1875), which is very rare.

Each of the species investigated has a different biology. However, they can be placed into three ecological groups based on their habitat preferences (Buchar \& Thaler, 1995; Buchar \& Růžicka, 2002): Five species prefer dry habitats - A. figurata (Simon, 1876), A. perita (Latreille, 1799), T. lutetiana (Simon, 1876), X. miniata (C.L. Koch, 1834), and $X$. nemoralis (Westring, 1861). Four species occur in humid habitats - A. alpigena lamperti Dahl, 1908, A. cinerea (Fabricius, 1777), A. leopardus (Sundevall, 1833), and $A$. maculata (Hahn, 1822). The remaining two are alpine species $-A$. alpigena (Doleschall, 1852) and A. renidescens Buchar \& Thaler, 1995.
The genera Arctosa and Tricca are closely related (Braun, 1963; Buchar, 1981) and placed by Petrunkevitch (1928) in the subfamily Lycosinae, whereas according to Zyuzin (1985) Xerolycosa belongs to the subfamily Evippinae. The relationships within the genus Arctosa remain to be resolved. Today, the genus Arctosa contains species placed formerly in separate genera and species of doubtful taxonomical position. The latter is the case for several central European species, namely the alpigenagroup $[A$. alpigena, $A$. a. lamperti, $A$. renidescens, and $A$. insignita (Thorell, 1872)] and A. figurata. Simon (1937) delimited the alpigena-group as a separate group within the genus Lycosa Latreille, 1804. Remarkably, most of the other Lycosa groups delimited in his study have currently a generic status. Concerning A. figurata, Zyuzin (1985) states that because of differences in the structure of its genitalia this species does not belong to the genus Arctosa. The synonymization of the genus Tricca with the genus Arctosa (Platnick, 2010) is not accepted here. Based on morphological characters differentiating both genera, the genus Tricca will be revalidated (Y.M. Marusik, P.T. Lehtinen \& P. Dolejš, unpubl.). Unlike the genus Arctosa the genus Xerolycosa is a well defined group containing only five species (Platnick, 2010).

In terms of cytogenetics, lycosids are one of the best explored families of entelegyne spiders along with the families Araneidae and Salticidae. Despite this, there are many lycosid genera for which the karyotypes are 
TABLE 1. Basic karyotypes of the genera Arctosa, Tricca, and Xerolycosa.

\begin{tabular}{|c|c|c|c|}
\hline Species & $2 n$ & $\mathrm{n}$ (male) & References \\
\hline \multirow{2}{*}{ Arctosa alpigena (Doleschall, 1852) } & $26(0)$ & $12+\mathrm{X}_{1} \mathrm{X}_{2}$ & Hackman, 1948 \\
\hline & $30($ ( ) & & this study \\
\hline Arctosa alpigena lamperti Dahl, 1908 & $28($ ( $)$ & $13+X_{1} X_{2}$ & this study \\
\hline Arctosa cinerea (Fabricius, 1777) & $28(0)$ & $13+X_{1} X_{2}$ & this study \\
\hline Arctosa figurata (Simon, 1876) & $28($ đ) & $13+X_{1} X_{2}$ & this study \\
\hline \multirow{2}{*}{ Arctosa leopardus (Sundevall, 1833) } & $26($ đ) & $12+\mathrm{X}_{1} \mathrm{X}_{2}$ & Hackman, 1948 \\
\hline & $28\left(\delta^{\hat{n}}\right)$ & $13+X_{1} X_{2}$ & this study \\
\hline Arctosa maculata (Hahn, 1822) & $28($ đ) & $13+X_{1} X_{2}$ & this study \\
\hline Arctosa mulani (Dyal, 1935) & $28($ đ) & $13+X_{1} X_{2}$ & Sharma et al., 1958 (sub. Pardosa mulani) \\
\hline \multirow{2}{*}{ Arctosa perita (Latreille, 1799) } & $12($ ㅇ) & & Akan et al., 2005 \\
\hline & $28($ ( $)$ & $13+X_{1} X_{2}$ & this study \\
\hline Arctosa renidescens Buchar \& Thaler, 1995 & $28($ đ) & $13+X_{1} X_{2}$ & this study \\
\hline \multirow{2}{*}{ Arctosa sp. } & $28($ đ) & $13+X_{1} X_{2}$ & Mittal, 1960 \\
\hline & $30($ ( $)$ & & Mittal, 1963 \\
\hline Tricca lutetiana (Simon, 1876) & $28($ đ) & $13+X_{1} X_{2}$ & this study \\
\hline \multirow{3}{*}{ Xerolycosa miniata (C.L. Koch, 1834) } & $22(0)$ & $10+X_{1} X_{2}$ & Hackman, 1948 \\
\hline & $22(0)$ & $10+X_{1} X_{2}$ & Gorlov et al., 1995 \\
\hline & $22(0)$ & $10+X_{1} X_{2}$ & this study \\
\hline \multirow{3}{*}{ Xerolycosa nemoralis (Westring, 1861) } & $26(0)$ & $12+X_{1} X_{2}$ & Hackman, 1948 \\
\hline & $22(0)$ & $10+\mathrm{X}_{1} \mathrm{X}_{2}$ & Gorlov et al., 1995 \\
\hline & $22(0)$ & $10+X_{1} X_{2}$ & this study \\
\hline
\end{tabular}

unknown or uncertain (Table 1). Up to now, 102 species of lycosids (including 23 species determined only to the genus level) from 21 genera have been analysed. These data were recently summarised by Král \& Buchar (1999) and Chemisquy et al. (2008); the list of the latter authors did not include six species studied by Yang et al. (1997), Bugayong et al. (1999), Akan et al. (2005), and Kumbiçak et al. (2009).

Diploid chromosome numbers of lycosid males range from $2 \mathrm{n}=18$ in Lycosa sp. (Srivastava \& Shukla, 1986) to $2 \mathrm{n}=28$ in most other species. Suzuki (1954) classified spider karyotypes into three types based on the number of chromosomes: (i) karyotypes with high chromosome numbers $(2 n>46$ in males) are regarded as primitive (mesothelids, mygalomorphs), (ii) those with $2 \mathrm{n}=34-46$ (the so-called intermediate type), and (iii) those with low chromosome numbers $(2 n<34)$. From this point of view, karyotypes of lycosids are of type iii, which is the most frequent type of karyotype recorded for spiders. C-values of the lycosid genome (1.83-4.18 pg, mean $2.65 \mathrm{pg}$ ) fall within the range of that recorded for entelegyne spiders (0.74-5.7 pg) (Gregory \& Shorthouse, 2003).

Lycosids have a "typical" entelegyne karyotype that is composed exclusively of acrocentric chromosomes (Rowell, 1990). C-banding revealed that on the chromosomes of lycosids there is a centromeric block of constitutive heterochromatin $(\mathrm{CH})$ (Table 2). Despite the uniform distribution of $\mathrm{CH}$ in the karyotype, particular species can differ considerably in the proportion of AT- and CG-rich heterochromatin (Chemisquy et al., 2008). The distribution of nucleolar organizer regions (NORs) has only been recorded for Allocosa georgicola (Walckenaer, 1837). Wise (1983) found that nucleoli are associated only with two autosome pairs in this species.
Most species of lycosids retain the original sex chromosome system of spiders, $\delta \mathrm{X}_{1} \mathrm{X}_{2} / q \mathrm{X}_{1} \mathrm{X}_{1} \mathrm{X}_{2} \mathrm{X}_{2}$ (the socalled $\mathrm{X}_{1} \mathrm{X}_{2} 0$ system) (Suzuki, 1954; Datta \& Chatterjee, 1989). In some species the sex chromosomes are the largest elements of the complement, e.g. as in Lycosa erythrognatha Lucas, $1836(2 \mathrm{n}=22)$ (Chemisquy et al., 2008). In Hippasa madhuae Tikader \& Malhotra, 1980 $(2 \mathrm{n}=28)$, the sex chromosomes are medium-sized (Parida et al., 1986). Schizocosa malitiosa (Tullgren, 1905) $(2 n=22)$ is reported to be polytypic for the size of the sex chromosomes (Chemisquy et al., 2008). In lycosid spiders, the $\mathrm{X}_{2}$ chromosome is usually only slightly shorter than $\mathrm{X}_{1}$. However, both sex chromosomes can differ considerably in size. For example, in Pardosa astrigera L. Koch, 1878 and Pirata piratoides (Bösenberg \& Strand, 1906), the $\mathrm{X}_{1}$ is the longest chromosome of the karyotype and $\mathrm{X}_{2}$ the shortest (Yang et al., 1996, 1997). Only in six species are there derived systems. The $\checkmark \mathrm{X} 0 /$ + XX system is reported in four wolf spiders: Lycosa nordenskjoldi Tullgren, 1905 (Diaz \& Saez, 1966), Schizocosa sp. of the malitiosa group (Postiglioni \& Brum-Zorrilla, 1981), Lycosa barnesi Gravely, 1924, and Wadicosa quadrifera (Gravely, 1924) (Srivastava \& Shukla, 1986). In Lycosa sp. of the thorelli group the o $\mathrm{X}_{1} \mathrm{X}_{2} \mathrm{X}_{3} /$ o $\mathrm{X}_{1} \mathrm{X}_{1} \mathrm{X}_{2} \mathrm{X}_{2} \mathrm{X}_{3} \mathrm{X}_{3}$ system is found (Postiglioni \& Brum-Zorrilla, 1981). An analysis of two closely related species of the thorelli group indicates that this system evolved from the $\mathrm{X}_{1} \mathrm{X}_{2} \mathrm{O}$ system by nondisjunction (Postiglioni \& Brum-Zorrilla, 1981). Finally, translocations between autosomes and sex chromosomes occur as polymorphism in a population in Pardosa morosa (L. Koch, 1870) (J. Král, unpubl.).

As in other spiders, the behaviour of $\mathrm{X}$ chromosomes of wolf spiders during male meiosis is peculiar. By 
TABLE 2. Localization of the constitutive heterochromatin $(\mathrm{CH})$ and nucleolar organizer regions (NORs) of the lycosids studied.

\begin{tabular}{|c|c|c|c|}
\hline Species & $\begin{array}{l}\text { Marker } \\
\text { studied }\end{array}$ & Localization & References \\
\hline Allocosa georgicola (Walckenaer, 1837) & NORs & Associated with two pairs of autosomes & $\begin{array}{l}\text { Wise, } 1983 \text { (sub. Lycosa } \\
\text { georgicola) }\end{array}$ \\
\hline Alopecosa albofasciata (Brullé, 1832) & $\mathrm{CH}$ & Medium sized blocks, pericentromeric location & Gorlova et al., 1997 \\
\hline Arctosa alpigena lamperti Dahl, 1908 & $\begin{array}{c}\mathrm{CH} \\
\mathrm{NORs}\end{array}$ & $\begin{array}{l}\text { Medium sized blocks, pericentromeric location } \\
\text { Third and eleventh pairs - distal location }\end{array}$ & this study \\
\hline Lycosa erythrognatha Lucas, 1836 & $\mathrm{CH}$ & Medium sized blocks, pericentromeric location & Chemisquy et al., 2008 \\
\hline Lycosa thorelli (Keyserling, 1877) & $\mathrm{CH}$ & Medium sized blocks, pericentromeric location & $\begin{array}{l}\text { Brum-Zorrilla \& Postiglioni, } \\
1980\end{array}$ \\
\hline Lycosa sp. & $\mathrm{CH}$ & Medium sized blocks, pericentromeric location & $\begin{array}{l}\text { Brum-Zorrilla \& Postiglioni, } \\
1980\end{array}$ \\
\hline Pardosa astrigera L. Koch, 1878 & $\mathrm{CH}$ & Medium sized blocks, pericentromeric location & Yang et al., 1996 \\
\hline Pirata piraticus (Clerck, 1757) & $\mathrm{CH}$ & Medium sized blocks, pericentromeric location & Peng et al., 1998 \\
\hline Pirata piratoides (Bösenberg \& Strand, 1906) & $\mathrm{CH}$ & Medium sized blocks, pericentromeric location & Yang et al., 1997 \\
\hline Schizocosa malitiosa (Tullgren, 1905) & $\mathrm{CH}$ & Medium sized blocks, pericentromeric location & $\begin{array}{l}\text { Brum-Zorrilla \& Cazenave, } \\
1974 \text { (sub. Lycosa malitiosa) }\end{array}$ \\
\hline Tricca lutetiana (Simon, 1876) & $\begin{array}{c}\mathrm{CH} \\
\mathrm{NORs} \\
\end{array}$ & $\begin{array}{c}\text { Tiny blocks, pericentromeric location } \\
\text { Eighth and eleventh pairs - distal location }\end{array}$ & this study \\
\hline Xerolycosa miniata (C.L. Koch, 1834) & $\begin{array}{c}\mathrm{CH} \\
\mathrm{NORs} \\
\end{array}$ & $\begin{array}{l}\text { Tiny blocks, pericentromeric location } \\
\text { Third and sixth pairs - distal location }\end{array}$ & this study \\
\hline Xerolycosa nemoralis (Westring, 1861) & $\begin{array}{c}\mathrm{CH} \\
\mathrm{NORs}\end{array}$ & $\begin{array}{l}\text { Tiny blocks, pericentromeric location } \\
\text { Third and sixth pairs - distal location }\end{array}$ & this study \\
\hline
\end{tabular}

prophase I they are located at the periphery of the nucleus, pair non-homologously without chiasma formation and segregate to one of the spindle poles as a single unit during anaphase I (e.g. Hackman, 1948). Furthermore, the male $\mathrm{X}$ chromosomes are more condensed than autosomes and thus stain more intensively (so-called positive heteropycnosis) during some meiotic stages, especially prophase I. Structures ensuring the pairing of non-homologous X chromosomes in Schizocosa malitiosa are visible when viewed under a transmission electron microscope. This revealed that $\mathrm{X}_{1}$ and $\mathrm{X}_{2}$ are connected by an unusual structure, designated the "junction lamina", from pachytene to diplotene (Benavente \& Wettstein, 1977). The junction lamina resembles the synaptonemal complex from which it differs in having a discoidal shape and indistinct central part.

The present study focused on the central European members of Arctosa, Tricca, and Xerolycosa. The diploid chromosome numbers, chromosome morphology, sex chromosome system, distribution of $\mathrm{CH}$ and NORs were determined and compared with those recorded for related species in the literature.

\section{MATERIAL AND METHODS}

Spiders were collected either by hand or by using dry pitfall traps. If necessary, they were reared to a stage suitable for analysis. Detailed data on the specimens examined are presented in Table 3. It was found that subadult (penultimate) and/or adult males are the most suitable for this type of analysis. Their testes contained spermatogonial mitoses and various stages of meiosis. Female mitotic metaphases were obtained from the intestine. Selected specimens are deposited in the collection of the National Museum, Prague (numbers P6A-4927-P6A-4931).
Suitable tissues were removed from the opisthosoma using fine scissors and placed in a physiological solution, developed for Ephestia Guenée, 1845 (Lockwood, 1961), on a wax plate. Chromosomes were prepared using a spreading technique (Traut 1976), with the following modifications: the gonads were hypotonized in $0.075 \mathrm{M} \mathrm{KCl}$ for $12-15 \mathrm{~min}$ at room temperature (RT) and fixed in two changes of freshly prepared ethanol : acetic acid p.a. (3:1) (standard preparations) or methanol : acetic acid p.a. (3:1) (standard preparations, preparations for silver staining and C-banding) for 10 and $20 \mathrm{~min}$ (RT). Using a pair of fine tungsten needles a cell suspension was prepared quickly and as finely as possible from a piece of tissue in a drop of $60 \%$ acetic acid on a clean slide. The preparation was placed on a histological plate heated to $40^{\circ} \mathrm{C}$ (standard preparations) or $33-34^{\circ} \mathrm{C}$ (to preserve the chromatin for silver staining or $\mathrm{C}$-banding). The cell suspension was moved by pushing it with a tungsten needle until the drop had almost evaporated. The remaining suspension was discarded. Preparations were stained the next day with 5\% Giemsa solution (Merck, Darmstadt, Germany) in Sörensen buffer (pH 6.8) for 27-28 min (RT).

The standard method of Sumner (1972) was used for C-banding. Preparations were stained with 5\% Giemsa solution in Sörensen buffer (pH 6.8) for 70 min (RT). Staining of NORs by $\mathrm{AgNO}_{3}$ was performed according to Howell \& Black (1980), with some modifications to standardise the method for lycosid chromosomes. Three drops of gelatine and seven drops of $\mathrm{AgNO}_{3}$ were dripped on the preparation (as the viscosity of these reagents differ the drops of gelatine are bigger than those of $\mathrm{AgNO}_{3}$ ) and mixed gently using a glass stick. The slide was covered by a cover slip, placed on a histological plate $\left(50-51^{\circ} \mathrm{C}\right)$ covered by four-layer cellulose cotton wool and incubated (4-5 $\mathrm{min}$ ) until solution was the colour of onion skin. Finally, the cover slide was removed under a gentle current of tap water and the preparation air-dried.

Preparations were inspected under a Jenaval (Carl Zeiss) or Olympus BX 50 microscope (Olympus). Selected plates were photographed using an immersion lens $100 \times$. The images were 
TABLE 3. List of species studied.

\begin{tabular}{|c|c|c|c|c|}
\hline Species & Locality & Co-ordinates & $\begin{array}{l}\text { Individuals } \\
\text { studied }\end{array}$ & Date(s) of experiment \\
\hline Arctosa alpigena & $\begin{array}{l}\text { Sportgastein (A), alpine meadow (cca } 2050 \text { m), } \\
\text { Kreuzkogel mountain, 20.vii.2008 (L.K. lgt., P.D. det.) }\end{array}$ & $\begin{array}{l}47^{\circ} 03^{\prime} \mathrm{N} \\
13^{\circ} 05^{\prime} \mathrm{E}\end{array}$ & 19 & 30.iv.2009 \\
\hline Arctosa alpigena lamperti & $\begin{array}{l}\text { Modrava (CZ), locality "Zadní mlynářská slat" near } \\
\text { the ford of the Roklanský potok brook }\end{array}$ & $\begin{array}{l}49^{\circ} 01^{\prime} \mathrm{N} \\
13^{\circ} 27^{\prime} \mathrm{E}\end{array}$ & $4 \mathrm{~s} \widehat{0}$ & $\begin{array}{l}\text { vii. } 2007, \text { viii. } 2007, \\
\text { vi. } 2008 *\end{array}$ \\
\hline Arctosa cinerea & Tušt' near Suchdol nad Lužnicí (CZ) & $\begin{array}{l}48^{\circ} 54^{\prime} \mathrm{N} \\
14^{\circ} 54^{\prime} \mathrm{E}\end{array}$ & 10 & 21.v.2004 \\
\hline Arctosa figurata & $\begin{array}{l}\text { Srbsko (CZ); locality “Komárkova lesostep”, the } \\
\text { Dř́nová hora mountain, 11.vi.2009 (P.D. lgt. et det.) }\end{array}$ & $\begin{array}{l}49^{\circ} 57^{\prime} \mathrm{N} \\
14^{\circ} 10^{\prime} \mathrm{E}\end{array}$ & 20 & 12.vi.2009 \\
\hline Arctosa leopardus & $\begin{array}{c}\text { Žleby (CZ); sandy warp, Doubrava river, 1.v.2009 } \\
\text { (P.D. lgt., J.B. det.) }\end{array}$ & $\begin{array}{l}49^{\circ} 53^{\prime} \mathrm{N} \\
15^{\circ} 29^{\prime} \mathrm{E}\end{array}$ & 10 & $\begin{array}{c}14 . v .2009 ; \text { collected as a } \\
\text { s and reared until adult } \\
\text { moult (10.v.2009) \# }\end{array}$ \\
\hline Arctosa maculata & Žilina near Nový Jičín (CZ), bank of Jičínka river & $\begin{array}{l}49^{\circ} 35^{\prime} \mathrm{N} \\
18^{\circ} 02^{\prime} \mathrm{E}\end{array}$ & 10 & 1.ix.1995 \\
\hline Arctosa perita & Mušlov near Mikulov (CZ) & $\begin{array}{l}48^{\circ} 47^{\prime} \mathrm{N} \\
16^{\circ} 41^{\prime} \mathrm{E}\end{array}$ & $3 \mathrm{~s} 0$ & 20.x.2003 \\
\hline Arctosa renidescens & Patsch (A), Patscherkofel mountain & $\begin{array}{l}47^{\circ} 12^{\prime} \mathrm{N} \\
11^{\circ} 27^{\prime} \mathrm{E}\end{array}$ & $4 \mathrm{~s} 0$ & 8.ix.2000 \\
\hline \multirow[t]{2}{*}{ Tricca lutetiana } & \multirow{2}{*}{$\begin{array}{l}\text { Srbsko (CZ); locality "Komárkova lesostep", the } \\
\text { Dřínová hora mountain (P.D. lgt. et det.) }\end{array}$} & \multirow{2}{*}{$\begin{array}{l}49^{\circ} 57^{\prime} \mathrm{N} \\
14^{\circ} 10^{\prime} \mathrm{E}\end{array}$} & $6 \mathrm{~s} 0^{\pi}$ & $\begin{array}{l}\text { xi.2005, viii. } 2006, \\
\text { v. } 2007 \#\end{array}$ \\
\hline & & & 40 & vi. 2005 , vi.2006, ix.2006 \\
\hline \multirow{5}{*}{ Xerolycosa miniata } & \multirow{2}{*}{ Brandýs nad Labem (CZ) } & \multirow{2}{*}{$\begin{array}{l}50^{\circ} 10^{\prime} \mathrm{N} \\
14^{\circ} 39^{\prime} \mathrm{E}\end{array}$} & $5 \mathrm{~s} 0^{+}$ & v.2005, xi.2005 \\
\hline & & & 10 & 13.v.2005 \\
\hline & \multirow{2}{*}{ Tušt' near Suchdol nad Lužnicí (CZ) } & \multirow{2}{*}{$\begin{array}{l}48^{\circ} 54^{\prime} \mathrm{N} \\
14^{\circ} 54^{\prime} \mathrm{E}\end{array}$} & $9 \mathrm{~s} 0^{\pi}$ & 28.v.2006 \\
\hline & & & $3 \sigma^{\pi}$ & 28.v.2006 \\
\hline & Praha - Hloubětín (CZ) & $\begin{array}{l}50^{\circ} 07^{\prime} \mathrm{N} \\
14^{\circ} 32^{\prime} \mathrm{E}\end{array}$ & $4 \mathrm{~s}^{\pi}$ & vi.2006, ix.2006 \\
\hline \multirow[t]{2}{*}{ Xerolycosa nemoralis } & \multirow{2}{*}{ Těptín (CZ) } & \multirow{2}{*}{$\begin{array}{l}49^{\circ} 53^{\prime} \mathrm{N} \\
14^{\circ} 35^{\prime} \mathrm{E}\end{array}$} & $7 \mathrm{~s} 0 \hat{~}$ & $\begin{array}{l}\text { vi.2006, viii.2006, } \\
\text { ix.2006 }\end{array}$ \\
\hline & & & 100 & vi.2006, x.2006 \\
\hline
\end{tabular}

A - Austria, CZ - Czech Republic, s - subadult, * the best stage for studying spermatogonial mitosis seems to be one week after moulting to the subadult stage, whereas for studying meiosis it is two weeks after this moult; \# subadult males were suitable for obtaining spermatogonial mitoses, complete meioses occur in males up to one week after the final moult.

recorded on a film (Kodak Technical Pan or Kodak Ilford Panf Plus 50) or by using a digital camera DP71 (Olympus). Well spread spermatogonial metaphases or sister metaphases II were used for karyotype analysis. The measurements were carried out using Image Tool 3 (UHTSCA, University of Texas Health Science Center at San Antonio, TX, USA) programme. Karyotypes were constructed in Corel Photo-Paint X3 (Version 13) software. Relative chromosome lengths were calculated as a percentage of the total chromosome length of the diploid set, including the sex chromosomes $(\% \mathrm{TCL})$. The $\mathrm{X}_{2} / \mathrm{X}_{1}$ ratio was calculated from ten spermatogonial metaphases and ten diplotene stages. Chromosome morphology was classified according to Levan et al. (1964). The mean chiasma frequency was calculated using the well spread complete diplotene plates for each species and dividing the total number of chiasmata by total number of bivalents.

\section{RESULTS}

\section{Arctosa C.L. Koch, 1847}

Karyotype and spermatogonial mitosis

The karyotypes consisted of 28 chromosomes (Fig. 1A-E). All chromosomes were acrocentric, except one subtelocentric autosome pair (No. 3) in A. alpigena and A. a. lamperti (Fig. 1D). The length of autosome pairs decreased gradually (Table 4), except in A. figurata and
A. perita (Fig. 1C). The first autosome pairs of these species were notably larger than the other autosome pairs. At mitotic metaphase, chromosomes were usually arranged radially. On the sixth chromosome pair in $A$. leopardus there was a distinct subterminal secondary constriction (Fig. 1B). In A. a. lamperti, the secondary constriction on the third autosome pair was adjacent to centromeric block of heterochromatin (Fig. 1D). The sex chromosome

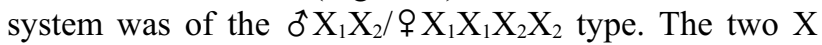
chromosomes were of unequal length (Table 4$)$. The length of chromosome $\mathrm{X}_{2}$ varied from $66.48 \%$ ( $A$. cinerea) to $94.10 \%$ (A. renidescens) of the length of chromosome $\mathrm{X}_{1}$. In $A$. cinerea (Fig. 1A), A. a. lamperti and $A$. maculata, the $\mathrm{X}_{1}$ at spermatogonial mitoses was the longest chromosome of the set. The $\mathrm{X}_{2}$ was usually the second longest chromosome (Table 4). In A. cinerea and $A$. leopardus, its length ranged between that of the second and third autosome pair. Arctosa perita is exceptional as the length of the $X_{1}$ lay between those of the seventh and eighth autosome pair, and $\mathrm{X}_{2}$ between the eleventh and twelfth pair. Sex chromosomes exhibited a slight positive heteropycnosis at metaphase in some species (A. cinerea, A. a. lamperti, A. leopardus, and A. perita). Moreover, one $(A$. cinerea) or both $(A$. perita) sex chromosomes 


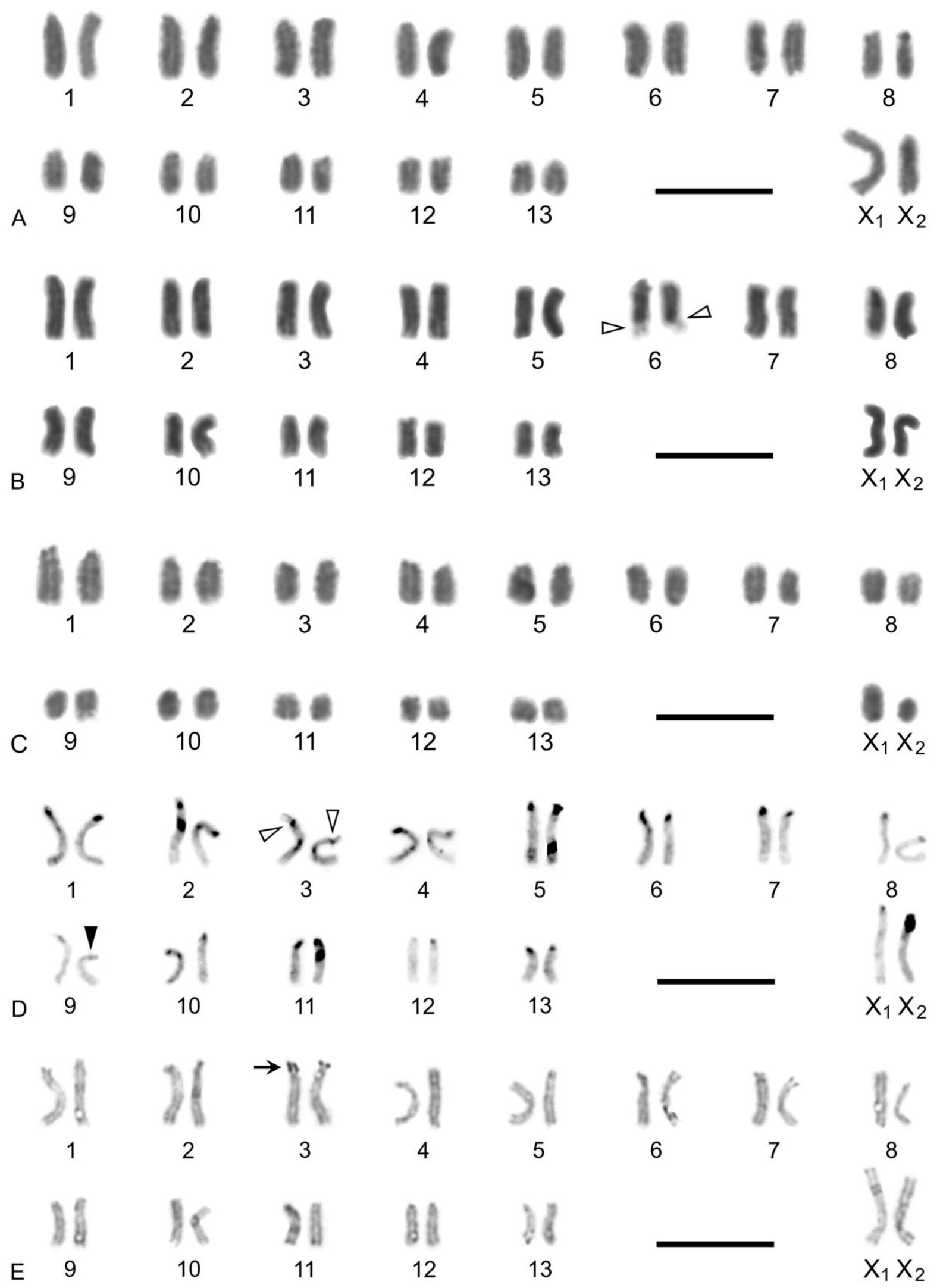

Fig. 1. A-E: Male karyotypes of Arctosa $\left(2 \mathrm{n} \widehat{\star}=28, \mathrm{X}_{1} \mathrm{X}_{2} 0\right)$ (based on spermatogonial metaphases). A - Arctosa cinerea. $\mathrm{B}-$ Arctosa leopardus. There are subterminal secondary constrictions (white arrowheads) on the sixth pair of autosomes. C - Arctosa perita, note relatively short sex chromosomes and difference in their size. D - Arctosa alpigena lamperti, C-banded figure. Note prominent blocks of centromeric $\mathrm{CH}$ on all chromosomes, a secondary constriction on the third pair of autosomes (white arrowheads), and a double block of proximal $\mathrm{CH}$ on one chromosome of pair No. 9 (black arrowhead). E - Arctosa alpigena lamperti, silver stained figure. There is an NOR at the proximal ends of the third pair and distal ends of the eleventh pair. One NOR is duplicated (arrow). Bars $=10 \mu \mathrm{m}$. 
TABLE 4. Relative chromosome lengths of every pair of autosomes and sex chromosomes of the species of Arctosa, Tricca, and Xerolycosa studied. For comparing male autosomes and gonosomes note that the relative length of one gonosome is half that of an appropriate pair of autosomes. $\mathrm{X}_{2} / \mathrm{X}_{1}-$ size ratio of chromosomes $\mathrm{X}_{2}$ and $\mathrm{X}_{1}$. ( $\mathrm{M}$ - spermatogonial metaphase, $\mathrm{D}$ - diplotene). Chiasma frequency, numbers in parenthesis - number of diplotenes studied in order to determine the chiasma frequency.

\begin{tabular}{|c|c|c|c|c|c|c|c|c|c|c|c|c|c|c|c|c|c|c|c|}
\hline \multirow[b]{2}{*}{ Genus } & \multirow[b]{2}{*}{ pecies } & \multirow[b]{2}{*}{ Sex } & \multicolumn{13}{|c|}{ Autosome pair No. } & \multicolumn{3}{|c|}{ Sex chromosomes } & \multirow[b]{2}{*}{$\begin{array}{l}\text { Chiasma } \\
\text { fre- } \\
\text { quency } \\
\text { (D) }\end{array}$} \\
\hline & & & 1 & 2 & 3 & 4 & 5 & 6 & 7 & 8 & 9 & 10 & 11 & 12 & 13 & $\mathrm{X}_{1} \quad \mathrm{X}_{2}$ & $\begin{array}{c}\mathrm{X}_{2} / \\
\mathrm{X}_{1} \\
(\mathrm{M}) \\
(\%)\end{array}$ & $\begin{array}{c}\mathrm{X}_{2} / \\
\mathrm{X}_{1} \\
(\mathrm{D}) \\
(\%)\end{array}$ & \\
\hline \multirow{5}{*}{ Arctosa } & & $\delta$ & 9.76 & 8.91 & 8.35 & 7.92 & 7.71 & 7.50 & 7.11 & 6.37 & 5.81 & 5.40 & 5.07 & 4.70 & 4.22 & 26.694 .45 & 66.48 & 871.05 & $(10)$ \\
\hline & A. fig & 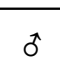 & 10.04 & 8.11 & 7.80 & 7.74 & 7.59 & 7.23 & 6.95 & 6.53 & 5.98 & 5.87 & 5.46 & 5.26 & 54.77 & $6.28 \quad 4.39$ & & 79.56 & \\
\hline & $\begin{array}{c}A . \\
\text { leopardus }\end{array}$ & 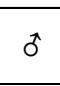 & 8.91 & 8.38 & 7.97 & 7.84 & 7.76 & 7.48 & 7.24 & 7.00 & 6.73 & 6.25 & 5.71 & 5.20 & 4.68 & $4.74 \quad 4.09$ & 86.09 & 970.75 & $\begin{array}{l}1.007 \\
(52)\end{array}$ \\
\hline & A. maculata & 10 & 8.99 & 8.49 & 8.43 & 7.93 & 7.68 & 7.45 & 6.90 & 6.59 & 6.24 & 5.83 & 5.44 & 5.14 & 46.67 & $5.45 \quad 4.70$ & 86.38 & 878.77 & \\
\hline & $a$ & đ & 10.93 & 9.71 & 8.78 & 8.37 & 8.05 & 7.58 & 7.17 & 6.68 & 6.08 & 5.76 & 5.25 & 4.99 & 4.62 & 3.462 .58 & 77.17 & 771.60 & $\begin{array}{r}1.0 \\
(1\end{array}$ \\
\hline \multirow{3}{*}{$\begin{array}{c}\text { Arctosa } \\
\text { alpigena- } \\
\text { group }\end{array}$} & alpigena & 9 & 26 & 97 & 59 & 55 & 7.04 & 6.78 & 6.02 & 5.85 & 5.62 & 5.44 & 5.05 & 4.93 & 34.32 & 9.138 .45 & 92.55 & & \\
\hline & $\begin{array}{l}\text { A. alpigena } \\
\text { lamperti }\end{array}$ & 0 & 8.68 & 8.32 & 8.13 & 7.86 & 7.62 & 7.32 & 6.97 & 6.68 & 6.25 & 6.07 & 5.82 & 5.74 & 5.10 & 4.924 .53 & 92.05 & 583.12 & \\
\hline & $\begin{array}{c}A . \\
\text { renidescens }\end{array}$ & 0 & 9.15 & 8.74 & 8.29 & 8.05 & 7.57 & 7.33 & 6.99 & 6.74 & 6.18 & 6.03 & 5.62 & 5.24 & 4.87 & 4.734 .45 & 94.10 & & $\begin{array}{c}1.004 \\
(20) \\
\end{array}$ \\
\hline cea & T. lut & 0 & 9.14 & 8.56 & 8.33 & 8.06 & 7.64 & 7.32 & 6.96 & 6.61 & 6.12 & 5.80 & 5.48 & 5.11 & 4.56 & 5.364 .94 & 92.66 & 688.66 & $\begin{array}{l}1.002 \\
(301) \\
\end{array}$ \\
\hline \multirow{2}{*}{$\begin{array}{c}\text { Xeroly- } \\
\text { cosa }\end{array}$} & $X$. miniata & đ & 11.361 & 10.92 & 10.15 & 9.66 & 9.33 & 8.96 & 8.69 & 8.58 & 8.15 & 7.54 & & & & 3.583 .07 & 86.69 & 978.44 & $\begin{array}{c}1.000 \\
(15)\end{array}$ \\
\hline & $\begin{array}{c}X . \\
\text { nemoralis }\end{array}$ & $\hat{\sigma}$ & 11.361 & 10.44 & 10.10 & 9.81 & 9.45 & 9.16 & 8.96 & 8.42 & 8.21 & 7.52 & & & & 3.443 .13 & 90.62 & 284.87 & $\begin{array}{l}1.019 \\
(37)\end{array}$ \\
\hline
\end{tabular}

exhibit slightly delayed separation of chromatids at metaphase. In other species, this phenomenon was not observed.

The pattern of $\mathrm{CH}$ and NORs was studied in A. a. lamperti. Metaphase chromosomes showed relatively large centromeric $\mathrm{CH}$ blocks (Fig. 1D). One chromosome of the ninth autosome pair bore a double block of $\mathrm{CH}$ proximally (Fig. 1D). The $\mathrm{X}_{1}$ chromosome had a relatively small amount of centromeric $\mathrm{CH}$ compared with $\mathrm{X}_{2}$ and autosomes. Two autosome pairs had terminal NORs. Length measurements indicate that the NORs are on the third (proximal position) and eleventh (distal position) pair of chromosomes (Fig. 1E). Duplication of the NOR on one chromosome of the third pair was visible on several plates of one specimen (Fig. 1E).

\section{Male meiosis}

Sex chromosomes manifested positive heteropycnosis from leptotene (Fig. 2A) and zygotene to diakinesis ( $A$. a. lamperti, $A$. maculata, $A$. renidescens), anaphase I (except metaphase I) (A. figurata), or metaphase II (except prophase II) (A. cinerea, A. leopardus, A. perita). By zygotene (Fig. 2B), the autosome bivalents showed a distinct polarization forming the typical bouquet persisting till pachytene (Fig. 2C). By pachytene, chromatin of each bivalent was differentiated into distinct chromomeres. Proximal ends of bivalents showed prominent centromeric knobs (Fig. 2C). In A. a. lamperti, the thirdlargest bivalent contained a secondary constriction (Fig. 2D). Sex chromosomes formed a body situated at the periphery of the nucleus (Fig. 2D). In hypotonized pachytene nuclei of females, sex chromosome bivalents were indistinguishable (Fig. 2C).

The diplotene stage is relatively long. Diplotene plates consisted of 13 bivalents. Sex chromosomes persisted in the form of a body till early diplotene (most species) (Fig. 3A) or late diplotene (A. a. lamperti) (Fig. 3B). After that, the sex chromosome body split up into particular sex chromosomes that were closely aligned but not associated. The sex univalents in late diplotene were either as long as the medium-sized autosome bivalents ( $A$. figurata, A. maculata, A. renidescens) (Fig. 3A) or nearly as short as the shortest autosome bivalent $(A$. a. lamperti, A. cinerea, A. leopardus, A. perita) (Fig. 3B). Both sex chromosomes differed in size (Table 4). The length of chromosome $\mathrm{X}_{2}$ varied from $70.75 \%$ (A. leopardus) to $83.12 \%$ (A. a. lamperti) of the length of chromosome $\mathrm{X}_{1}$. Some plates contained one or two bivalents with two chiasmata (one proximal and one distal) (Table 4). In contrast to the other species, bivalents of $A$. figurata and $A$. perita had always only one (usually proximal) chiasma.

The so-called terminalization of chiasmata (seeming shift of chiasmata to the ends of bivalents due to spiralization of chromosomes) occurred at diakinesis (Fig. 3C) in Arctosa as well as in the following genera. At metaphase I, all bivalents segregated at the same time (Fig. 3D). By anaphase I, the two X chromosomes behaved as a unit and moved together to the same pole. This resulted in two types of anaphase I plates. At this stage, the sister chromatids of autosomes were associated only by their centromeres and thus had a V-shaped appearance, whereas chromatids of sex chromosomes had not sepa- 

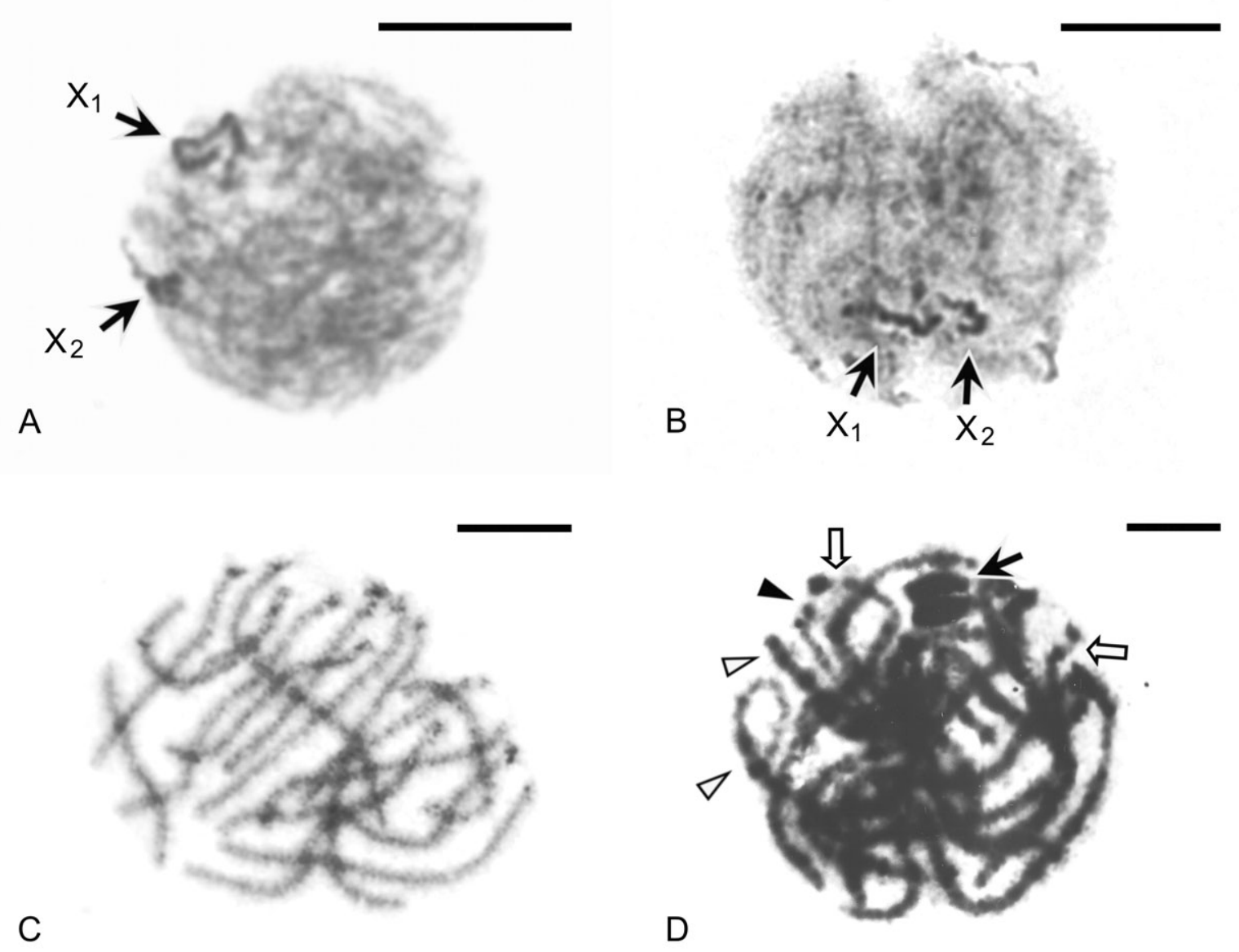

Fig. 2. A-D: Arctosa, early prophase I. A - Arctosa leopardus ( $\left.\delta^{\star}\right)$, leptotene, sex chromosomes are located at the periphery of the nucleus (arrows). B - Arctosa perita ( $\widehat{0})$, late zygotene, bivalents form bouquet, sex chromosomes are heteropycnotic (arrows). C Arctosa alpigena (\$), pachytene consists of 15 bivalents forming a bouquet, note centromeric knobs at proximal ends of bivalents. $\mathrm{D}$ - Arctosa alpigena lamperti ( $\left.\delta^{*}\right)$, pachytene, sex chromosomes are aligned in parallel (black arrow) at the periphery of the nucleus. Note interchromomeres (white arrowheads), terminal knobs (black arrowhead) and subterminal secondary constrictions (white arrows). Bars $=10 \mu \mathrm{m}$.

rated (Fig. 3E). The chromosomes were comparatively larger than at metaphase I due to some decondensation of chromatin. Two types of metaphases II were observed: one with 15 elements (13 autosomes and $\left.\mathrm{X}_{1} \mathrm{X}_{2}\right)$ and the other with only 13 autosomes (Fig. 3F). The sex chromosomes exhibited slightly delayed separation of chromatids. In $A$. a. lamperti, the chromatids of all chromosomes were coiled at metaphase II (Fig. 3F).

\section{Tricca lutetiana (Simon, 1876)}

Spermatogonial mitosis

The mitotic plates consisted of 28 acrocentric chromosomes (Fig. 4A). Length of autosome pairs decreased gradually (Table 4). Third-largest autosome pair had a distinct subterminal secondary constriction. The sex chro-

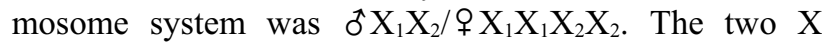
chromosomes were the longest chromosomes of the karyotype, but they differed in size (Table 4). However, they were morphologically indistinguishable from the autosomes. Metaphase chromosomes had a minute centromeric $\mathrm{CH}$ block (Fig. 4A). Longer chromosomes had a usually somewhat larger amount of $\mathrm{CH}$ than the shorter ones, the $\mathrm{CH}$ of which was hardly visible. Two autosome pairs (the eighth and eleventh) possessed a distal NOR (Fig. 4B).

\section{Male meiosis}

By leptotene, sex chromosomes formed two intensely stained structures. Sex chromosomes retained positive heteropycnosis up to early diplotene. By zygotene, bivalents were arranged in the typical bouquet. At zygotene and pachytene, the sex chromosomes were situated at the periphery of the nucleus forming a heterochromatinic body both in standard and C-banded preparations (Fig. 4C). Chromatin of pachytene bivalents formed distinct chromomeres. At early diplotene (Fig. 5A) 13 autosome bivalents and a body formed by two sex chromosomes were observed. However, at late diplotene (Fig. 5B), the sex chromosome body suddenly decondensed into two rod-like chromosomes, which were as long as the longest autosome bivalent. Both sex univalents differed in size (Table 4). During this period, they were isopycnotic with the autosomes (Fig. 5B). An achromatic decondensed region appeared on each sex univalent approximately in the proximal third or quarter (Fig. 5B, C). The position of the constriction differed between both sex univalents 

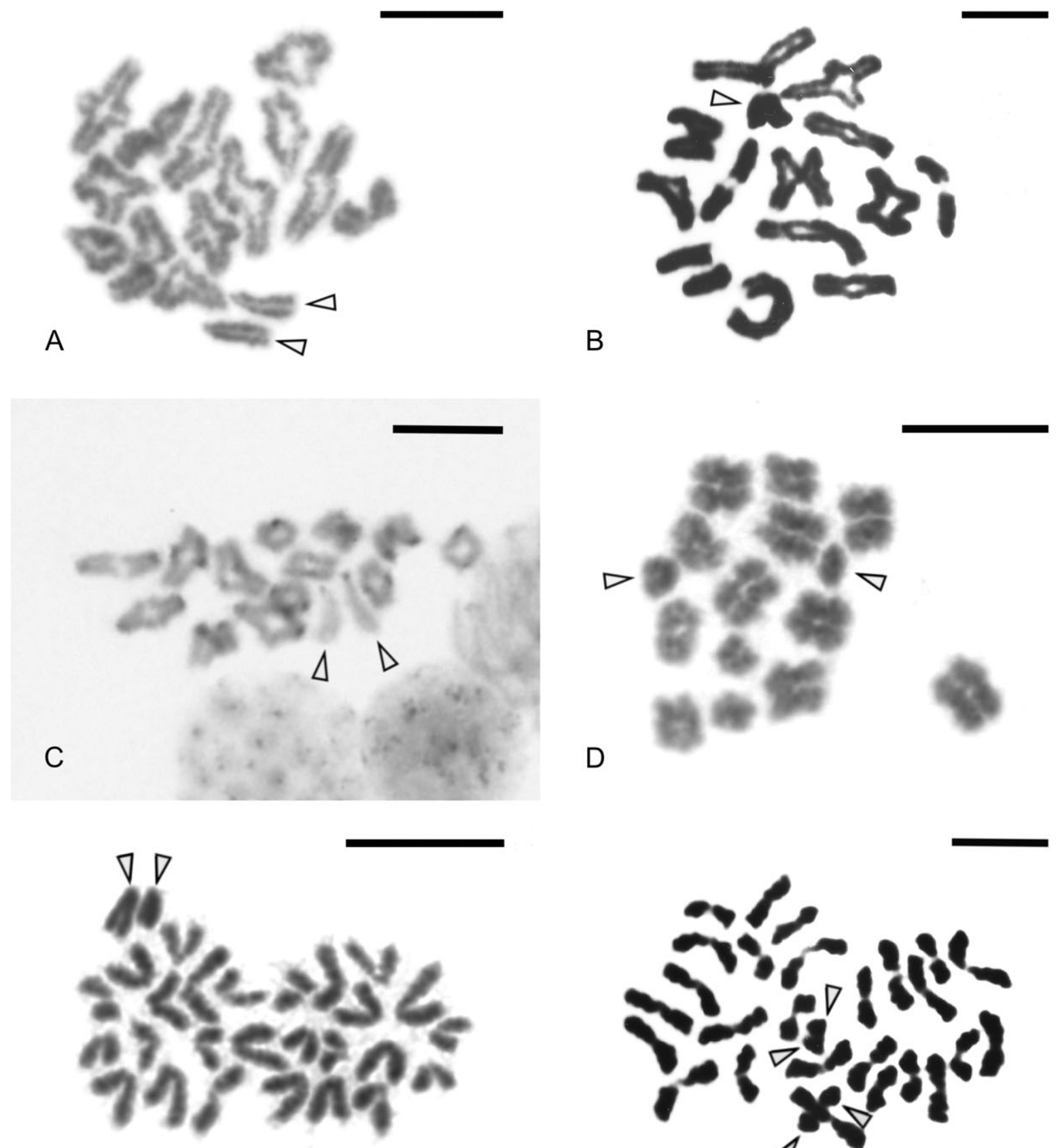

$\mathrm{E}$

F

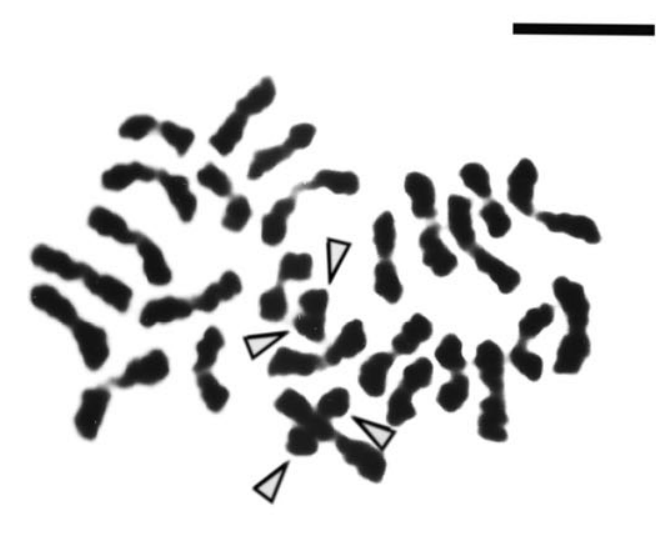

Fig. 3. A-F: Arctosa $\left(2 \mathrm{n} \widehat{\widehat{\sigma}}=28, \mathrm{X}_{1} \mathrm{X}_{2} 0\right)$, male meiosis, continued. Arrowheads indicate sex chromosomes. A - Arctosa figurata, diplotene, the sex univalents are arranged in parallel. B - Arctosa alpigena lamperti, diplotene, the X univalents are paired proximally. C - Arctosa alpigena lamperti, C-banded diakinesis. The centromeric regions of the X univalents, which are formed of constitutive heterochromatin, converge. D - Arctosa cinerea, metaphase I. E - Arctosa cinerea, anaphase I. F - Arctosa alpigena lamperti, two sister metaphase II, chromosomes are coiled to form macrocoils (Ohnuki coils). Bars $=10 \mu \mathrm{m}$.

(Fig. 5B). In most cases, each bivalent had one (usually proximal) chiasma (Table 4, Fig. 5A-D). The sex chromosomes recondensed at diakinesis (Fig. 5D) and remained loosely associated at the periphery of the nucleus. The course of following meiotic stages does not differ from those of Arctosa.

\section{Xerolycosa Dahl, 1908}

Spermatogonial mitosis

The mitotic plates contained 22 chromosomes (Fig. 6A). All chromosomes were acrocentric and decreased gradually in size (Table 4). They were usually arranged radially at metaphase. The sex chromosome system was $\mathrm{X}_{1} \mathrm{X}_{2} 0$. The two gonosomes were the shortest chromosomes; however, they were of different size (Table 4). $\mathrm{CH}$ and NORs were studied in both species. Chromosomes 


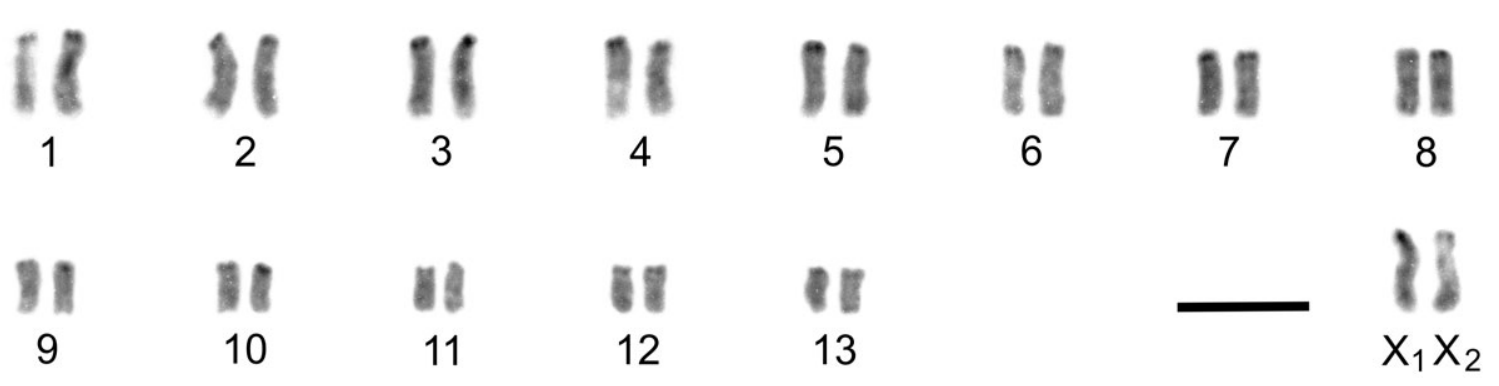

A
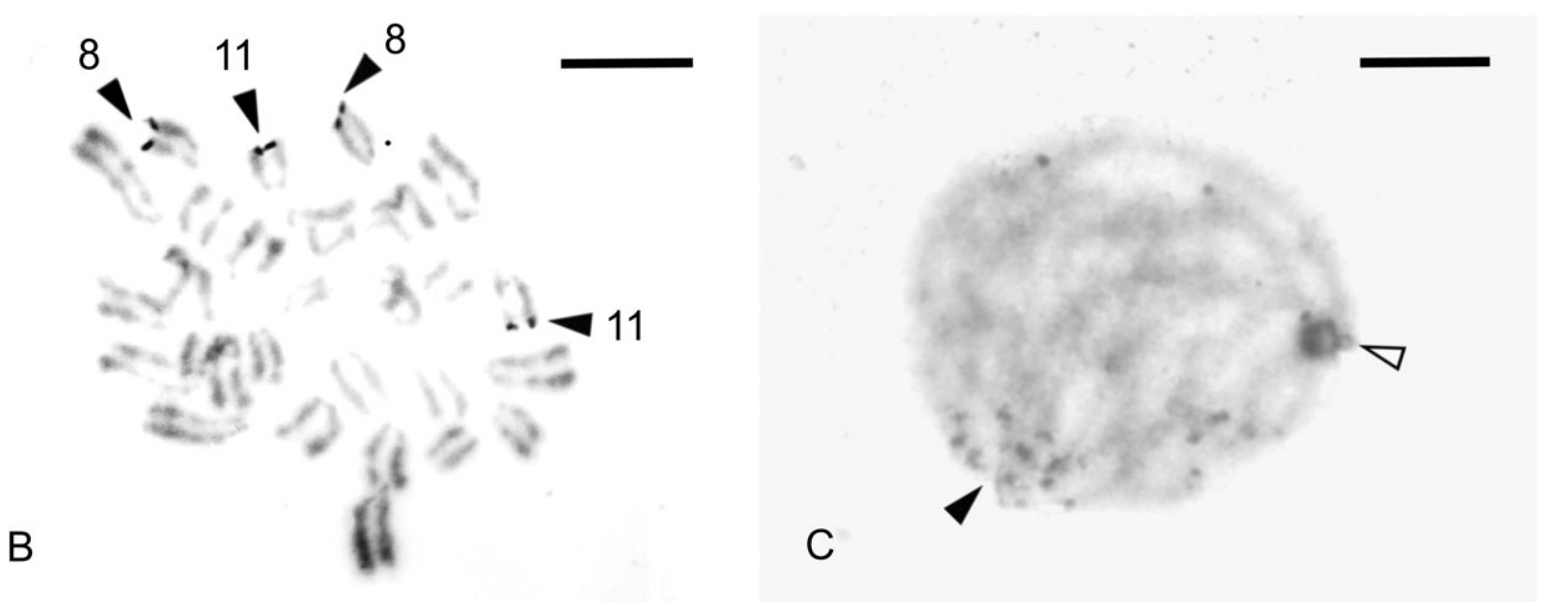

Fig. 4. A-C: Male of Tricca lutetiana $\left(2 \mathrm{n} \hat{0}=28, \mathrm{X}_{1} \mathrm{X}_{2} 0\right)$. A - karyotype (based on a C-banded spermatogonial metaphase). Chromosomes contain a low amount of $\mathrm{CH}$, which is located in the centromeric regions. $\mathrm{B}$ - silver-stained late mitotic metaphase. Note there are NORs at the distal ends of autosome pairs No. 8 and 11 (black arrowheads). C - C-banded pachytene. Note completely heterochromatinized sex body (white arrowhead). Due to arrangement of autosome bivalents into bouquet, most pericentromeric blocks of heterochromatin form a cluster at the periphery of the nucleus (black arrowhead). Bars $=10 \mu \mathrm{m}$.

showed minute, not clearly recognisable, centromeric $\mathrm{CH}$ blocks (Fig. 6B). Two pairs of autosomes (the third and sixth pair) had distal NORs (Fig. 6C). The duplication of NORs on one chromosome of the third pair was seen on several plates of both species (Fig. 6C).

\section{Male meiosis}

During leptotene, sex chromosomes formed two positively heteropycnotic structures. The pattern of sex chromosome heteropycnosis was different in both species. In $X$. nemoralis, heteropycnosis disappeared by early diplotene. In contrast, heteropycnosis persisted until anaphase I in $X$. miniata. The course of zygotene and pachytene was similar to that in the genera Arctosa and Tricca. At pachytene, positively heteropycnotic sex chromosomes formed a sex body, which was situated at the periphery of the nucleus.

During diplotene in $X$. miniata (Fig. 7A), ten autosome bivalents and two sex chromosomes were closely associated with each other. The sex chromosomes differed in size (Table 4). They started to separate at early diplotene and were always nearly as short as the shortest autosome bivalent. Each bivalent had only one (usually proximal) chiasma. At diakinesis (Fig. 7B), the sex univalents were situated in parallel at the periphery of the nucleus.
At early diplotene in $X$. nemoralis (Fig. 7C), ten autosome bivalents and a body formed by sex chromosomes were observed. The sex chromosomes were the shortest chromosomes. However, at late diplotene (Fig. 7D), the sex univalents decondensed suddenly forming two parallel rods, which were as long as the longest autosome bivalent. Proximal parts of sex chromosomes were achromatic and separated by a conspicuous constriction. At this stage, the sex chromosomes were isopycnotic with the autosomes (Fig. 7D). In most cases, each autosome bivalent had one (usually proximal) chiasma. Occasionally, one to three pairs formed ring bivalents with proximal and distal chiasmata (Table 4). In early diakinesis, the sex chromosomes appear isopycnotic with autosomes; their proximal constrictions were still visible (Fig. 7E). The sex chromosomes re-condensed at late diakinesis (Fig. 7F).

During anaphase I (Fig. 8A) in both Xerolycosa species, the segregation of autosomes and sex chromosomes was analogous to those described in Arctosa. At metaphase II (Fig. 8B), two types of spermatocytes were present, namely with twelve (ten autosomes and $\mathrm{X}_{1} \mathrm{X}_{2}$ ) and ten chromosomes (ten autosomes). The sex chromosomes of $X$. miniata exhibit slightly delayed separation of chromatids (Fig. 8B). 


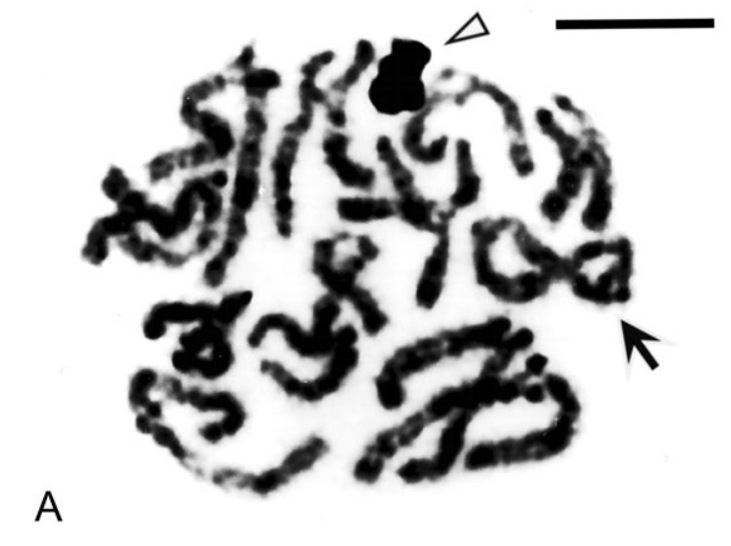

B
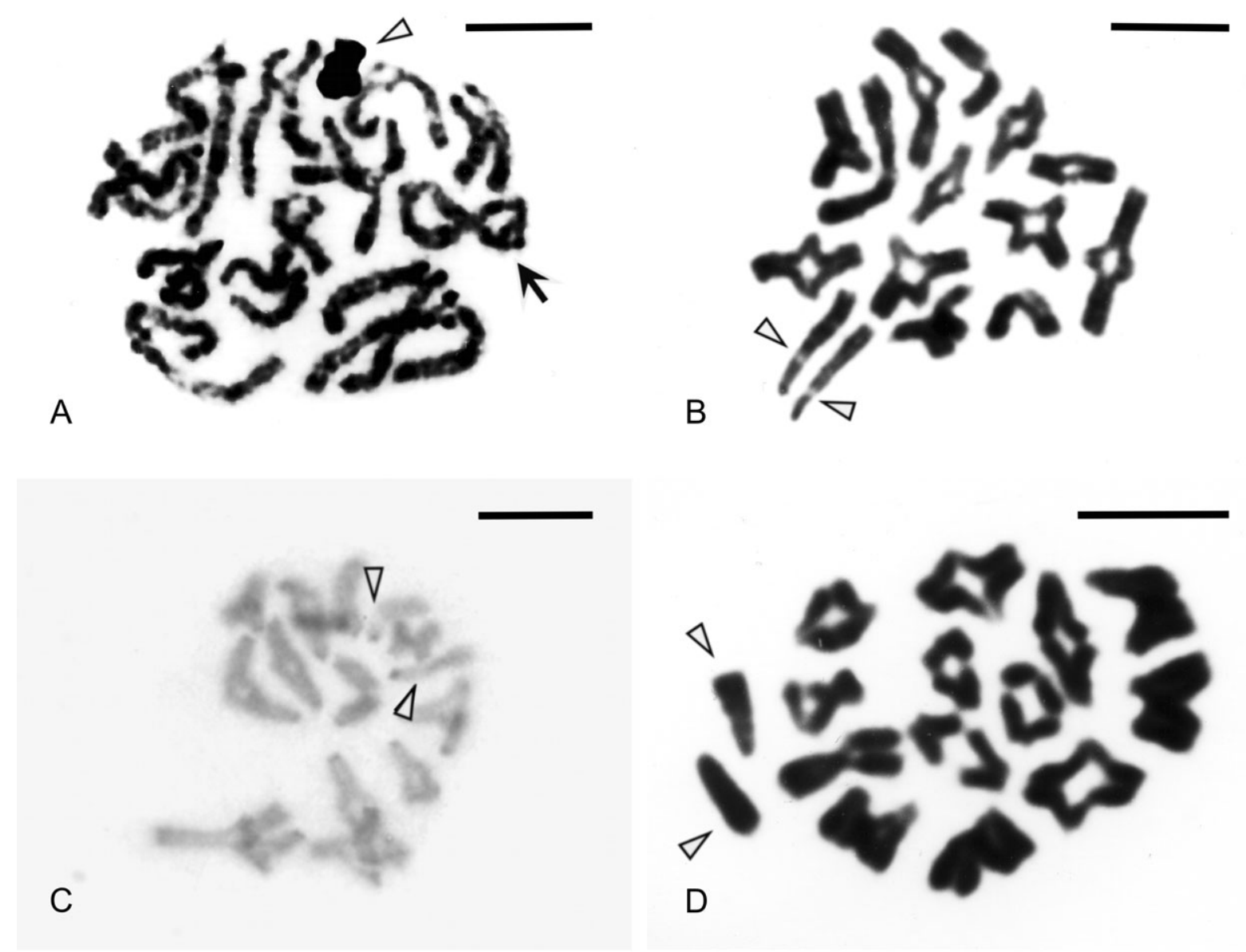

Fig. 5. A-D: Tricca lutetiana $\left(2 \mathrm{n} \hat{0}=28, \mathrm{X}_{1} \mathrm{X}_{2} 0\right)$, male prophase $\mathrm{I}$. A - the sex body (arrowhead) is located at the periphery of the nucleus in early diplotene. Note a bivalent with two chiasmata (arrow). B - sex chromosomes are aligned in parallel and partially decondensed, with achromatic regions at their proximal ends (arrowheads) in late diplotene. C - C-banded diplotene, sex chromosomes have achromatic regions at their proximal ends (arrowheads). D - diakinesis, sex chromosomes (arrowheads) are recondensed and loosely associated. Bars $=10 \mu \mathrm{m}$.

\section{DISCUSSION AND CONCLUSIONS}

Present study provides basic karyotype data for eleven central European lycosid spiders of the genera Arctosa, Tricca and Xerolycosa. The former two genera are placed by Petrunkevitch (1928) in the subfamily Lycosinae, the latter genus belongs, according to Zyuzin (1985), to Evippinae. Six species were studied for the first time and the karyotype data for another five species revised (Table 1). The chromosome number recorded for $X$. nemoralis corresponds with that reported for Siberian populations studied by Gorlov et al. (1995) but differs from that reported for Finish spiders by Hackman (1948). The data presented here for A. alpigena and A. leopardus also differ from that reported by Hackman (1948). Furthermore, the diploid number for $A$. perita recorded in this study is incongruent with that reported from Turkey by Akan et al. (2005). Misidentification of spiders by these authors is unlikely as these species are relatively easy to identify. The discrepancies may be due to either interpopulation variability in chromosome numbers or the chromosome numbers cited by these authors are incorrect. As interspecific variability in chromosome numbers in entelegyne spiders is in general very low (Brum-Zorrilla
\& Postiglioni, 1980; Král, 1994; Chen, 1999) the latter possibility seems to be the most likely. The techniques currently used to prepare chromosomes often produce incomplete plates, which was also the case in the present study. Moreover, the method of chromosome preparation used by Hackman (1948) did not include treatment with a hypotonic solution so the spreading of chromosomes is likely to have been less pronounced than in the present study. Therefore, that author probably failed to determine the correct chromosome number of A. alpigena, A. leopardus and $X$. nemoralis. Results provided by Akan et al. (2005) for A. perita are also problematic. The published chromosome plates are of very low quality and not suitable for determining chromosome numbers. The reported $2 \mathrm{n}$ for females $(2 \mathrm{n}=12)$ is improbable as the lowest diploid number recorded in lycosids so far is $2 \mathrm{n}=18$ in a male of Lycosa sp. from India (Srivastava \& Shukla, 1986). Similarly, the results for other species presented in that study are also improbable. The authors record $2 \mathrm{n}=$ 16 for a female of the theraphosid spider, Chaetopelma olivaceum (C.L. Koch, 1841) (sub. C. anatolicum Schmidt \& Smith, 1995), whereas unpublished results (J. 


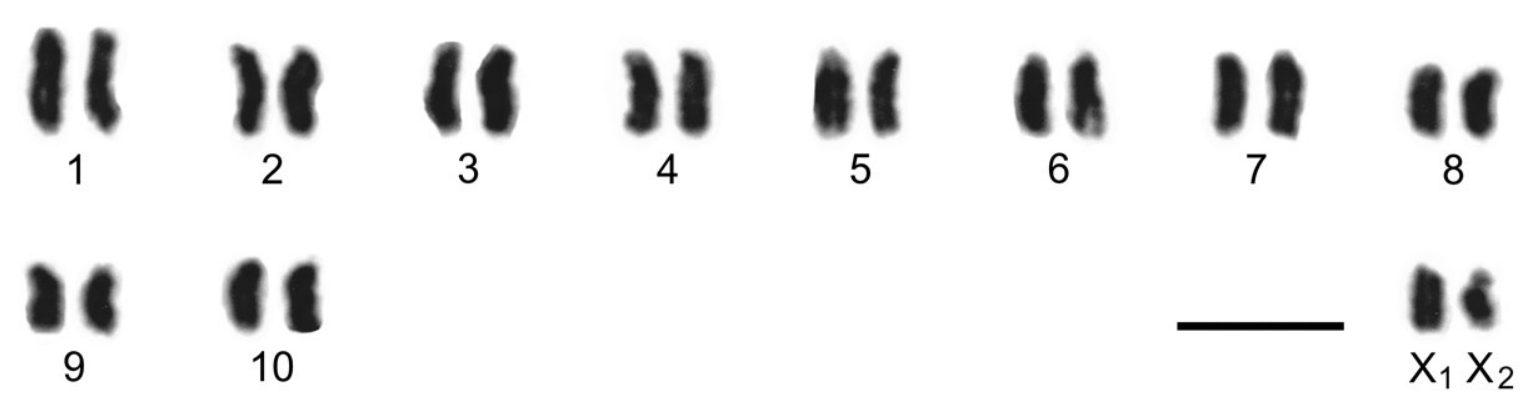

A

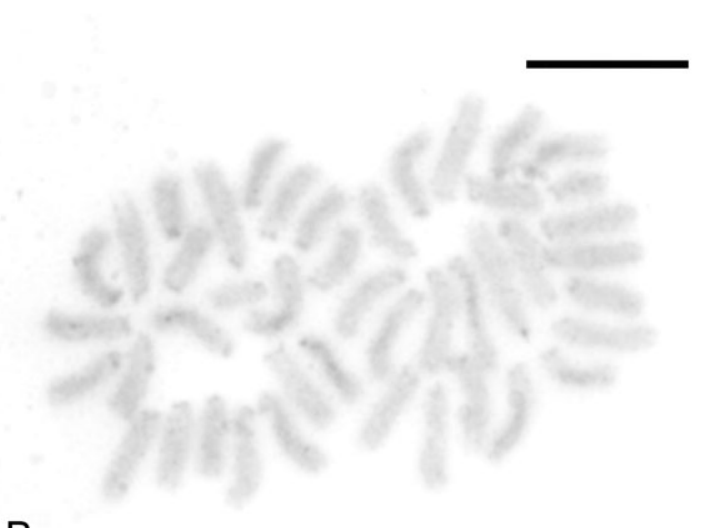

B

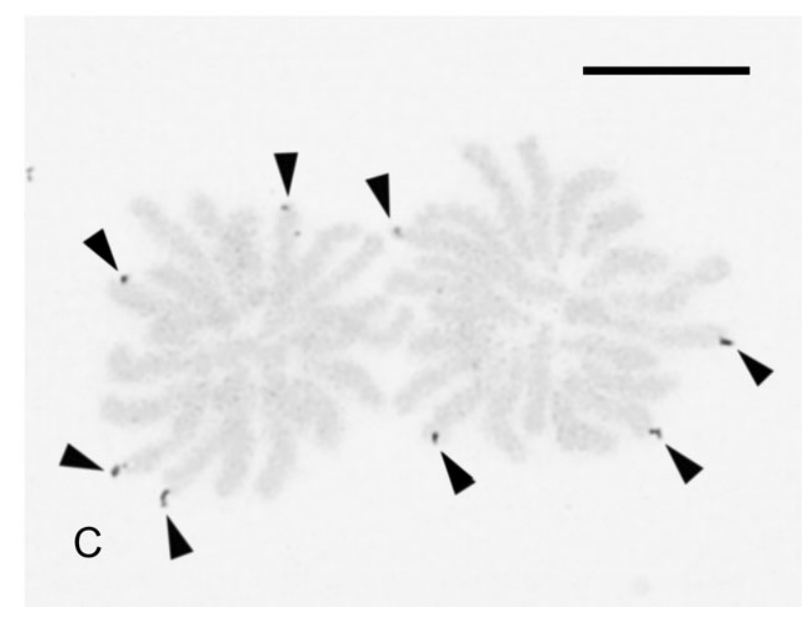

Fig. 6. A-C: Mitotic metaphase of Xerolycosa $\left(2 \mathrm{n} \hat{\imath}=22, \mathrm{X}_{1} \mathrm{X}_{2} 0\right)$. A - Xerolycosa nemoralis, karyotype. B - Xerolycosa nemoralis, C-banding, there is a negligible amount of $\mathrm{CH}$ in centromeric regions of chromosomes. $\mathrm{C}$-Xerolycosa miniata, NORs present at distal ends of two pairs of autosomes (arrowheads). Bars $=10 \mu \mathrm{m}$.

Král, unpubl.) indicate a much higher $2 \mathrm{n}$ for species of this genus ( $>60$ chromosomes).

Currently there are karyotypes recorded for 108 species of lycosid (Chemisquy et al., 2008; Kumbiçak et al., 2009; this study). Male karyotype of 28 chromosomes is found in $56 \%$ of the species, $2 n=22$ in $18 \%, 2 n=26$ in $12 \%$ and $2 \mathrm{n}=24$ in $8 \%$. Other diploid chromosome numbers $(2 \mathrm{n}=27,23,20,19$ and 18) are recorded for only one or two species (see Chemisquy et al., 2008 for a review). The results presented here support the idea of previous authors (Sharma et al., 1958; Datta \& Chatterjee, 1989; Král \& Buchar, 1999) that the ancestral karyotype of lycosid males consists of 28 acrocentric chromosomes. This chromosome number was recorded in this study for all central European species of the genera Arctosa and Tricca. Based on the compilation of Král \& Buchar (1999) and Giroti et al. $(2005,2007)$ it is suggested that $2 n=28$ is also the ancestral karyotype of the related families Trechaleidae, Pisauridae, Oxyopidae, Ctenidae, and Senoculidae. Hence it could be the ancestral karyotype for the whole superfamily Lycosoidea sensu lato (sensu Jocqué \& Dippenaar-Schoeman, 2007).

During the evolution of some lycosid lineages, diploid chromosome numbers were gradually reduced, as in other entelegyne spiders, most probably by tandem fusions (Suzuki, 1954). Decrease by cycles of Robertsonian translocations and subsequent pericentric inversions suggested by White (1973) is less probable because karyotypes of lycosids do not contain biarmed (i.e. metacentric or submetacentric) autosome pair(s). Reduced chromosome numbers were found in almost all the lycosid subfamilies examined (Evippinae, Lycosinae, Pardosinae, Venoniinae s. lat. including Piratinae and Wadicosinae) in addition to the ancestral number of $2 \mathrm{n}=28$ (see Chemisquy et al., 2008 for review). A tendency towards reduced chromosome numbers is particularly obvious in the subfamilies Lycosinae, Evippinae, and Venoniinae s. lat. as is evident from the derived karyotypes of both species of Xerolycosa $(2 n=22)$. Heterogeneity of diploid chromosome numbers in the subfamily Lycosinae is due to variability of $2 \mathrm{n}$ in the genus Lycosa (18-28 chromosomes). However, the variability in Lycosa reflects the absence of a modern taxonomic revision of this genus rather than a tendency towards a reduction in $2 \mathrm{n}$. Therefore, considerable reductions in $2 \mathrm{n}$ most probably only occur in the latter two subfamilies. Interestingly, molecular data (Murphy et al., 2006) place these subfamilies in a monophyletic clade. Such congruence between karyotype and molecular data is interesting.

The sex chromosome system found in all species is of

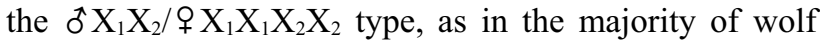
spiders studied (see Chemisquy et al., 2008 for review). 

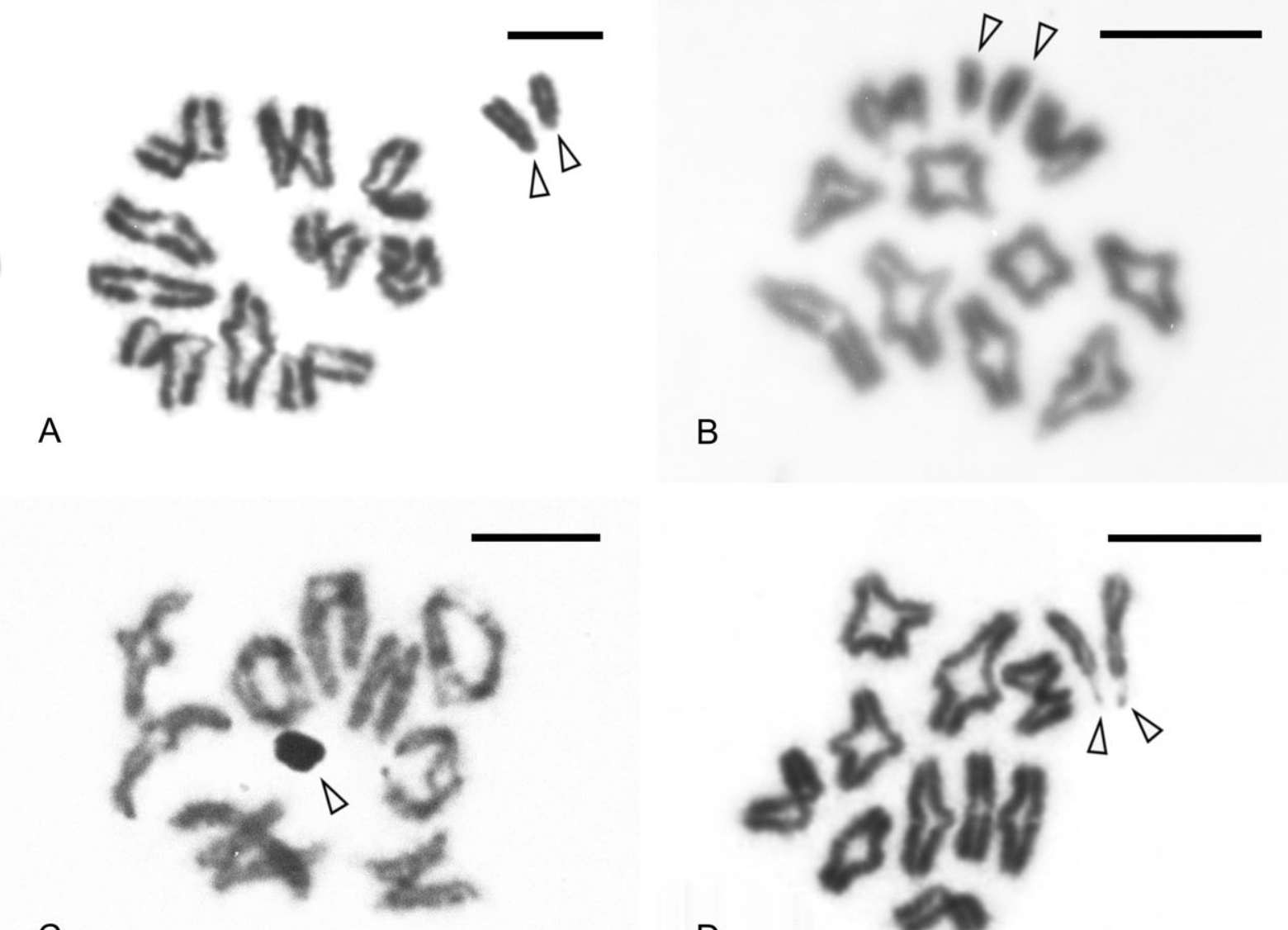

C
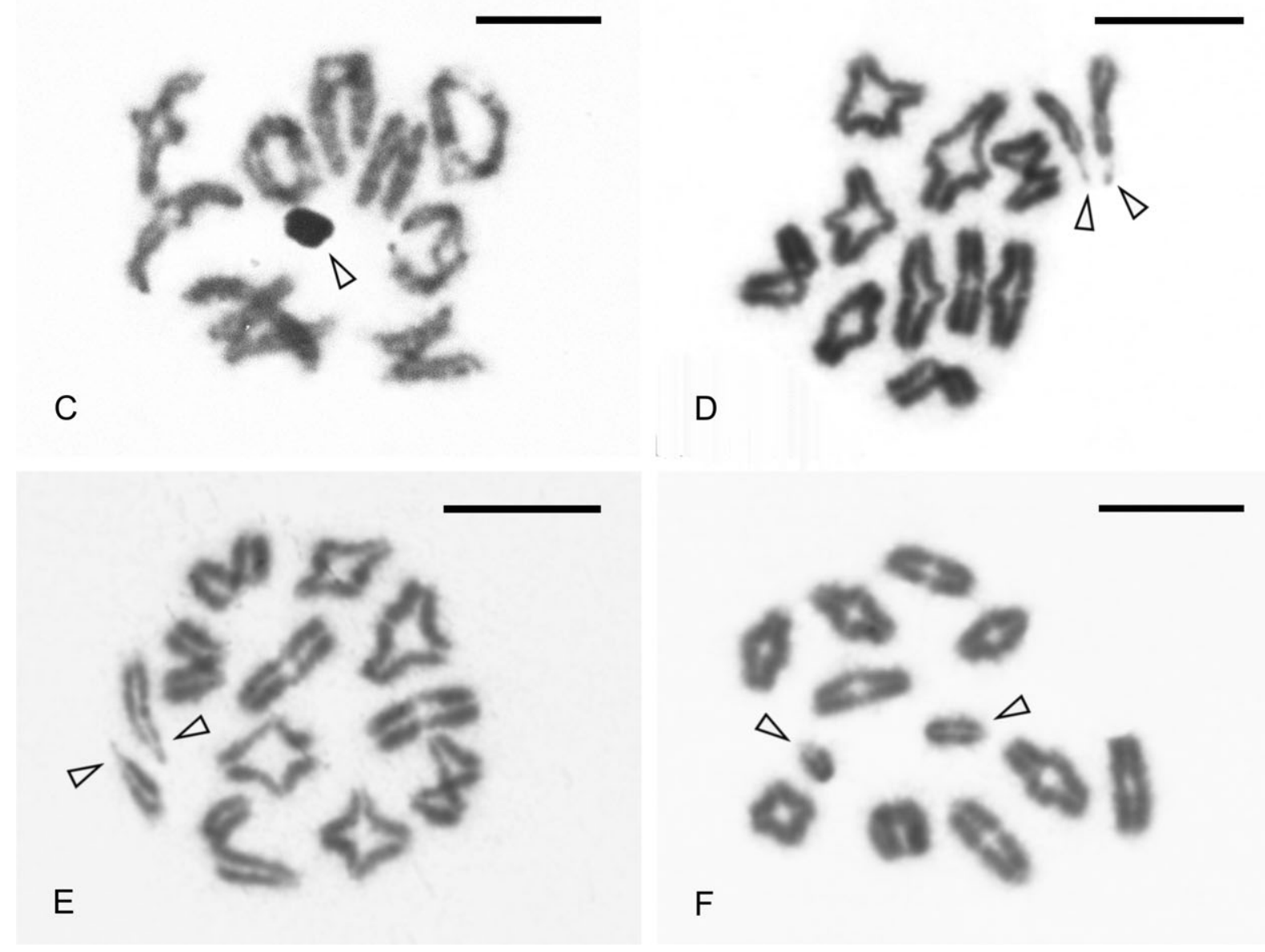

Fig. 7. A-F: Xerolycosa $\left(2 \mathrm{n} \widehat{0}=22, \mathrm{X}_{1} \mathrm{X}_{2} 0\right)$, male prophase I. Arrowheads - sex chromosomes. A, B: Xerolycosa miniata. A - sex chromosomes are aligned at the periphery of the nucleus at late diplotene. $\mathrm{B}-$ the sex chromosomes are aligned in parallel at early diakinesis. C-F: Xerolycosa nemoralis. C - sex chromosomes form a body at early diplotene. Note one ring bivalent. D - sex chromosomes are partially decondensed at late diplotene. Proximal regions of the sex chromosomes are achromatic. E - sex chromosomes are still partially decondensed at early diakinesis. F - sex chromosomes are recondensed and separate at late diakinesis. Bars $=10 \mu \mathrm{m}$.

This system is thought to be the ancestral type for spiders (Suzuki, 1954) including Lycosidae (Datta \& Chatterjee, 1989). In all species examined, sex chromosomes were unequal in length. The length difference of $\mathrm{X}_{1}$ and $\mathrm{X}_{2}$ chromosome was usually smaller at diplotene than in spermatogonial metaphases, possibly a consequence of more intensive condensation of sex chromosomes at diplotene. Interestingly, the difference in the length of the $\mathrm{X}_{1}$ and $\mathrm{X}_{2}$ chromosome is often species-specific and less or more variable among related species (Table 4). Differences in the size of the sex chromosomes could reflect evolutionary changes in the amount of sex chromosome heterochromatin. The quantity of $\mathrm{CH}$ and its distribution often changes quickly during evolution (King, 1993). 


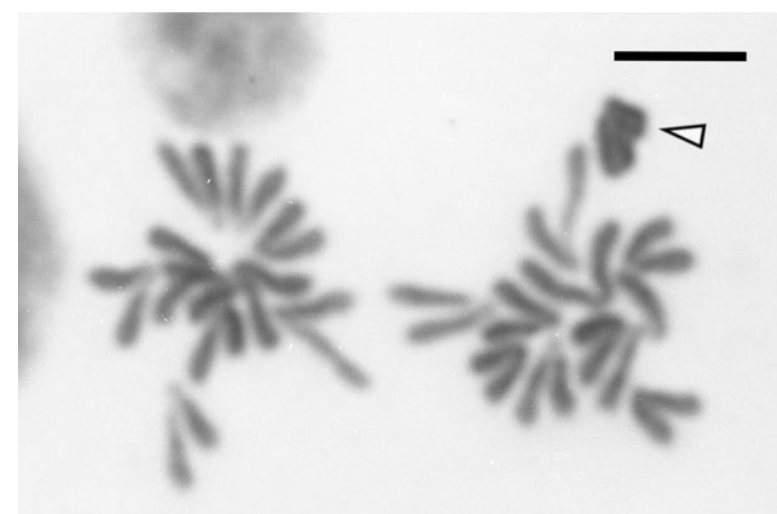

A

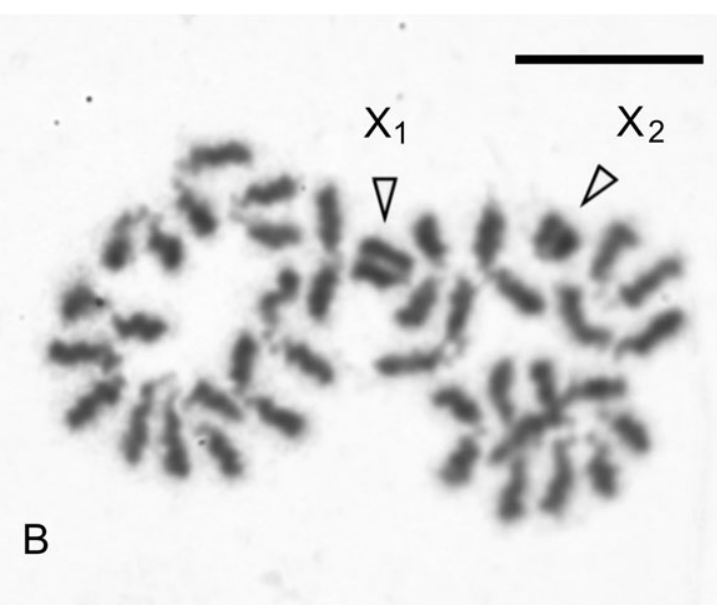

Fig. 8. A-B: Xerolycosa miniata $\left(2 \mathrm{n} \hat{\jmath}=22, \mathrm{X}_{1} \mathrm{X}_{2} 0\right)$, male meiosis, continued. A - heteropycnotic sex chromosomes (arrowhead) are close together at anaphase I. B - at metaphase II the heteropycnotic sex chromosomes (with their chromatids not yet separate) are at the periphery of the right plate (arrowheads). Bars $=10 \mu \mathrm{m}$.

However, the heterochromatin content of the sex chromosomes of the lycosids studied is too low to account for the relatively large change in the $\mathrm{X}_{2} / \mathrm{X}_{1}$ ratio, even between related species. Therefore, it is assumed that differences in the sizes of sex chromosomes can reflect also the rearrangement of sex chromosomes, especially deletions (Suzuki, 1952) or translocations between sex chromosomes. The sex chromosomes were the two longest chromosomes in the karyotype of most species. In $A$. cinerea and $A$. leopardus, the $\mathrm{X}_{1}$ was the longest chromosome while the length of $\mathrm{X}_{2}$ ranged between that of the second and third autosomal pair. In $A$. perita, the length of $\mathrm{X}_{1}$ was between that of the seventh and eighth autosomal pair, and $\mathrm{X}_{2}$ between the eleventh and twelfth pair. In both Xerolycosa species, the two gonosomes were the shortest chromosomes. These differences may be a consequence of the rearrangements of sex chromosomes and/or autosomes, which resulted in changes in their size, most probably due to translocations. The occurrence of autosomal translocations is indicated also by the fact that the first pair of autosomes of two Arctosa species ( $A$. perita and A. figurata) was notably larger than the other pairs of autosomes, whereas in all the other species of Arctosa the pairs of autosomes gradually decreased in size. Translocations could result in the development of barriers to reproduction between species (King, 1993) and therefore, could affect karyotype evolution in the genus Arctosa.

Distribution of $\mathrm{CH}$ in spiders has been studied only in representatives of several families of both basal araneomorphs (Král et al., 2006) and entelegyne araneomorphs. In entelegyne spiders, $\mathrm{CH}$ is recorded in some species of the families Salticidae (Gorlova et al., 1997), Tetragnathidae (Araújo et al., 2005), Sparassidae (Rowell, 1985; Rodríguez-Gil et al., 2007), Agelenidae (Král, 2007), and Lycosidae (this work, Table 2). Entelegyne spiders have centromeric $\mathrm{CH}$ and sometimes a tiny telomeric block on several chromosomes. Only centromeric $\mathrm{CH}$, without detectable distal blocks, is known for lycosids (see Table 2 for references). This pattern in the distribution of $\mathrm{CH}$ is believed to be the ancestral type for spiders
(Rodríguez-Gil et al., 2007). Genera Arctosa, Tricca, and Xerolycosa have only centromeric $\mathrm{CH}$. In wolf spiders studied previously (Table 2) the blocks of $\mathrm{CH}$ are relatively large. In this study relatively large blocks were found also in $A$. a. lamperti. In contrast to this, the blocks in the remaining three species ( $T$. lutetiana and both Xerolycosa species) were very small. The sex chromosomes in the species investigated had the same distribution and amount of heterochromatin as the autosomes. According to the data presented, sex chromosomes of wolf spiders consist mostly of euchromatin and are heterochromatinized facultatively at male meiosis as in other spiders (Datta \& Chatterjee, 1989; Král, 2007; Rodríguez-Gil et al., 2007). Predominance of $\mathrm{CH}$ in sex chromosomes has been reported only in a few spiders, namely three species of lycosids. Thus, $\mathrm{X}$ chromosomes were found to be formed only of $\mathrm{CH}$ at spermatogonial metaphases in Lycosa sp. (Brum-Zorrilla \& Postiglioni, 1980) and male diplotene in Alopecosa albofasciata (Gorlova et al., 1997). Similarly, one sex chromosome of female Schizocosa malitiosa was suggested to be formed only of $\mathrm{CH}$ at mitotic metaphase (Brum-Zorrilla \& Cazenave, 1974). The results presented indicate that C-banded sex chromosomes were completely heterochromatinized in some nuclei at the zygotene and pachytene stages of meiosis. During the later stages of meiosis and mitosis, sex chromosomes had the standard distribution of heterochromatin blocks. Therefore, complete heterochromatinization of C-banded sex chromosomes at the onset of meiosis reflected the fact that they were very condensed rather than predominance of $\mathrm{CH}$. In this manner, it is possible to explain also complete heterochromatinization of sex chromosomes after application of C-banding in above mentioned species, especially heterochromatinization of meiotic sex chromosomes reported by Gorlova et al. (1997).

In the present study, silver-staining was used for the first time to detect NORs of wolf spiders. The location of NORs has been recorded only for some basal araneomorph (Král et al., 2006; Oliveira et al., 2007; Araujo et 
al., 2008) and entelegyne spiders (Wise, 1983; Král, 1995; Araújo et al., 2005; Rodríguez-Gil et al., 2007). Unlike in the entelegynes, NORs of basal araneomorphs are often situated on sex chromosomes (Král et al., 2006). In all the lycosids studied (Table 2), two autosome pairs have an NOR. This distribution and number of NORs are reported for representatives of three unrelated families of entelegyne spiders, Nephilidae (Araújo et al., 2005), Sparassidae (Rodríguez-Gil et al., 2007), and Lycosidae (this study). Therefore, this pattern could be ancestral one for entelegyne spiders.

In T. lutetiana, the pairs of chromosomes No. 8 and 11 have distal NORs. Arctosa a. lamperti has a different pattern of NORs. The NOR on chromosome pair No. 11 is located at the distal end whereas that on subtelocentric chromosome pair No. 3 is located at the proximal end. Despite the little information on the position of NORs in spiders, they appear to be rarely proximally located. This situation is reported only for one autosome pair of two basal araneomorphs, Diguetia albolineata (O.P.-Cambridge, 1895) (Diguetidae) and Monoblemma muchmorei Shear, 1978 (Tetrablemmidae) (Král et al., 2006). Therefore, the pericentromeric position of NOR in A. a. lamperti is probably a derived character. This NOR may have been translocated onto the third pair from a former location on the eighth pair, which is its position in the closely related genus Tricca. There are no pairs of subtelocentric autosomes in other species of Arctosa (except $A$. alpigena) so that pericentromeric NORs could be restricted only to species closely related to $A$. a. lamperti. Therefore, it would be worth examining the evolution of NORs in the remaining species of the "alpigena-group".

Interestingly, the duplication of NORs was found on one chromosome pair of $A$. a. lamperti and Xerolycosa species. This duplication probably occurred in the heterozygous state, as it was only found on one chromosome of the pair. NOR duplications seem to be common in entelegyne spiders; they are reported also in representatives of the families Agelenidae (Král, 1995, 2007) and Nephilidae (Araújo et al., 2005).

Similar to other lycosids the genera analysed exhibit a low chiasma frequency during meiosis. By diplotene, most bivalents have only one chiasma. In general, a low chiasma frequency is typical for acrocentric chromosomes (e.g. John, 1990). Although the course of meiosis is the same in all the lycosid genera studied here, the particular species differ considerably in many details of sex chromosome behaviour, some of which appeared as speciesspecific characters. The most remarkable is the behaviour of the sex chromosomes in $T$. lutetiana and $X$. nemoralis at late prophase I. Sex chromosomes of these species exhibit partial decondensation and are isopycnotic with autosome bivalents at late diplotene, whereas those of the other species are condensed and exhibit positive heteropycnosis. During that period, proximal parts of sex chromosomes of $T$. lutetiana bear curious achromatic regions. In order to consider the taxonomical significance of this feature, it would be necessary to examine the meiotic behaviour of sex chromosomes in taxa potentially related to Tricca (e.g. the genus Triccosta Roewer, 1960 and Arctosa species that were included in the former genera Leaena Simon, 1885 and Leaenella Roewer, 1960). The occurrence of constrictions on the $\mathrm{X}$ chromosomes of $X$. nemoralis at diplotene could also have some taxonomic importance because they appear in $X$. nemoralis but not in $X$. miniata. Therefore, the question is whether they occur also in other Xerolycosa species. Concerning the constrictions, it would be worth examining the meiotic sex chromosomes in males of the genera potentially related to Xerolycosa (e.g. the genus Evippa Simon, 1885).

Although karyotypes of Arctosa species are all characterized by the same diploid number, chromosome morphology and sex chromosome system, they differ in many details. The same was found in the genus Xerolycosa. In view of the low karyotype diversity in both genera, their cytotaxonomy is likely to be best resolved using molecular cytogenetic methods that are suitable for studying the evolution of conservative karyotypes.

ACKNOWLEDGEMENTS. We would like to thank B. Knoflach-Thaler (Leopold-Franzens-Universität, Innsbruck) for providing us with specimens of Arctosa renidescens, M. Forman and A. Sember (Charles University in Prague) for technical assistance and M. Kubec for all-round assistance with collecting the specimens. Collecting of Tricca lutetiana in Karlštejn National Nature Reserve was permitted by the decree of the government of the Czech Republic no. 1159/07. Collecting of Arctosa alpigena lamperti in Sumava National Park (NPS) was allowed by the decree SZ NPS 03028/2007/3 - NPS 04091/2007. We also thank to two anonymous reviewers for valuable comments and suggestions for improving this paper and to the language editor of the Eur. J. Entomol. (A.F.G. Dixon) for correcting our English. Our research was funded by two projects of the Grant Agency of the Charles University, GAUK 208/2005B-BIO/PrF (L.K., J.M., J.K., V.O., P.D.) and GAUK 140907 (P.D., J.M., J.B.), a project of the Czech Science Foundation No. 206/08/0813 (J.K., T.K., J.M.) and by a research grant from the Ministry of Education, Youth and Sports MSM 002162828 (J.K., T.K., L.K., J.M.).

\section{REFERENCES}

AKan Z., VAROL I. \& ÖZASLAN M. 2005: A cytotaxonomical investigation on spiders (Arachnida: Araneae). Biotechnol. Biotec. Eq. 19: 101-104.

Araújo D., Cella D.M. \& Brescovit A.D. 2005: Cytogenetic analysis of the neotropical spider Nephilengys cruentata (Araneomorphae, Tetragnathidae): standard staining, NORs, C-bands and base-specific fluorochromes. Braz. J. Biol. 65 : 193-202.

Araujo D., Rheims C.A., Brescovit A.D. \& Cella D.M. 2008: Extreme degree of chromosome number variability in species of the spider genus Scytodes (Araneae, Haplogynae, Scytodidae). J. Zool. Syst. Evol. Res. 46: 89-95.

Benavente R. \& Wettstein R. 1977: An ultrastructural cytogenetic study on the evolution of sex chromosomes during the spermatogenesis of Lycosa malitiosa (Arachnida). Chromosoma 64: 255-277.

Blick T., Bosmans R., Buchar J., Gajdoš P., Hänggi A., Van Helsdingen P., RŮŽičKa V., Staręga W. \& Thaler K. 2004: Checkliste der Spinnen Mitteleuropas. Checklist of the Spiders of Central Europe. (Arachnida: Araneae). Version 1. December 2004. Online at http://www.arages.de/checklist. html\#2004_Araneae. 
Braun R. 1963: Das Tricca-Problem (Arach., Araneae). Senck. Biol. 44: 73-82.

Brum-Zorrilla N. \& Cazenave A.M. 1974: Heterochromatin localization in the chromosomes of Lycosa malitiosa (Arachnida). Experientia 30: 94-95.

Brum-Zorrilla N. \& Postiglioni A. 1980: Karyological studies on Uruguayan spiders. I. Banding pattern in chromosomes of Lycosa species (Araneae-Lycosidae). Genetica 54: 149-153.

Buchar J. 1981: Zur Lycosiden-Fauna von Tirol (Araneae, Lycosidae). Věst. Čs. Spol. Zool. 45: 4-13.

Buchar J. \& RƯžIČKa V. 2002: Catalogue of Spiders of the Czech Republic. Peres, Praha, 351 pp.

Buchar J. \& Thaler K. 1995: Die Wolfspinnen von Österreich 2: Gattungen Arctosa, Tricca, Trochosa (Arachnida, Araneida: Lycosidae) - Faunistisch-tiergeographische Übersicht. Carinthia II 185/105: 481-498.

Bugayong M.J.G., Barrion A.A. \& PAPAG R.B. 1999: Karyotype of the egg chromosomes of the wolf spider Hippasa holmerae Thorell (Araneae: Lycosidae). Philipp. Agric. Scientist 82: 296-299.

Chemisquy M.A., Rodríguez Gil S.G., Scioscia C.L. \& Mola L.M. 2008: Cytogenetic studies of three Lycosidae species from Argentina (Arachnida, Araneae). Genet. Mol. Biol. 31: $857-867$.

CHEN S.-H. 1999: Cytological studies on six species of spiders from Taiwan (Araneae: Theridiidae, Psechridae, Uloboridae, Oxyopidae, and Ctenidae). Zool. Stud. 38: 423-434.

Datta S.N. \& ChatterJee K. 1989: Study of meiotic chromosomes of four hunting spiders of north eastern India. Perspect. Cytol. Genet. 6: 417-424.

Diaz M.O. \& SAEz F.A. 1966: Karyotypes of South-American Araneida. Mem. Inst. Butantan Simp. Internac. 33: 153-154.

Giroti A.M., de Araujo D., Cella D.M. \& Brescovit A.D. 2005: Cromossomos de duas espécies de Lycosoidea e duas de "Dionycha" (Araneae, Entelegynae) e comparações citogenéticas entre famílias. In Primer Congreso Latinoamericano de Aracnología. Resúmenes. Sección Citogenética y Bioquímica, p. 108 (Abstract), online at http://www.aracneo. org/TEXTOS/citogenetica\%20y\%20bioquimica.pdf.

Giroti A.M., Araujo D., Oliveira E.G., Brescovit A.D. \& Cella D.M. 2007: Cytogenetics of some true lycosoid spiders (Araneomorphae): Chromosomes of two Lycosa species (Lycosidae) and possible occurrence of B-chromosomes in Trechalea sp. (Trechaleidae). In $17^{\text {th }}$ International Congress of Arachnology, Abstracts. São Pedro, São Paulo, Brazil, p. 245 (Abstract), online at http://www.ib.usp.br/ ricrocha/ ISA17/CONGRESSOCOMPLETO.pdf.

Gorlov I.P., Gorlova O.Y. \& Logunov D.V. 1995: Cytogenetic studies on Siberian spiders. Hereditas 122: 211-220.

Gorlova O.Y., Gorlov I.P., Nevo E. \& Logunov D.V. 1997: Cytogenetic studies on seventeen spider species from Israel Bull. Br. Arachnol. Soc. 10: 249-252.

Gregory T.R. \& Shorthouse D.P. 2003: Genome size of spiders. J. Hered. 94: 285-290.

HaCKMAN W. 1948: Chromosomenstudien an Araneen mit besonderer Berücksichtigung der Geschlechtschromosomen. Acta Zool. Fenn. 54: 1-101.

Howell W.M. \& Black D.A. 1980: Controlled silver-staining of nucleolus organizer regions with a protective colloidal developer: a 1-step method. Experientia 36: 1014-1015.

Jocqué R. \& DippenaAR-SChoeman A.S. 2007: Spider Families of the World. Royal Museum for Central Africa, Tervuren, $336 \mathrm{pp}$.

John B. 1990: Meiosis. 3rd ed. Cambridge University Press, Cambridge, $396 \mathrm{pp}$.
KInG M. 1993: Species Evolution: The Role of Chromosome Change. Cambridge University Press, Cambridge, 337 pp.

KRÁL J. 1994: Přehled cytogenetiky pavoukovců [Review of arachnid cytogenetics]. Biol. Listy 59: 282-306 [in Czech].

KRÁL J. 1995: The karyotype studies in central Europe's species of the superfamilies Amaurobioidea and Dictynoidea (Araneida). In Růžicka V. (ed.): Proceedings of the $15^{\text {th }}$ European Colloquium of Arachnology. Institute of Entomology, České Budějovice, p. 224 (Abstract).

KRÁL J. 2007: Evolution of multiple sex chromosomes in the spider genus Malthonica (Araneae: Agelenidae) indicates unique structure of the spider sex chromosome systems. Chromosome Res. 15: 863-879.

KRÁL J. \& BUCHAR J. 1999: Karyology of wolf spiders (Lycosidae). In Pekár S. \& Sunderland K.D. (eds): 18th European Colloquium of Arachnology. Programme, Abstracts, Addresses and Notes. Stará Lesná, p. 33 (Abstract).

Král J., Musilová J., ŠŤ́hllavský F., Řezáč M., Akan Z., Edwards R.L., Coyle F.A. \& AlmerJe C.R. 2006: Evolution of the karyotype and sex chromosome systems in basal clades of araneomorph spiders (Araneae: Araneomorphae). Chromosome Res. 14: 859-880.

Kumbiçak Z., Ergene S. \& Saygideğer S. 2009: Chromosomal data on six araneomorph spiders belonging to the families Lycosidae and Gnaphosidae. Zool. Middle East 48: 89-96.

Levan A.K., Fredga K. \& Sandberg A.A. 1964: Nomenclature for centromeric position on chromosomes. Hereditas 52: 201-220.

Lockwood A.P. 1961: "Ringer" solutions and some notes on the physiological basis of their ionic composition. Comp. Biochem. Physiol. 2: 241-289.

Mittal O.P. 1960: Chromosome number and sex mechanism in twenty species of the Indian spiders. Res. Bull. (N.S.) Panjab Univ. 11: 245-247.

MitTAL O.P. 1963: Karyological studies on the Indian spiders. I. A comparative study of the chromosomes and sexdetermining mechanism in the family Lycosidae. Res. Bull. (N.S.) Panjab Univ. 14: 59-86.

Murphy N.P., Framenau V.W., Donnellan S.C., Harvey M.S., PARK Y.-C. \& Austin A.D. 2006: Phylogenetic reconstruction of the wolf spiders (Araneae: Lycosidae) using sequences from the 12S rRNA, 28S rRNA, and NADH1 genes: Implications for classification, biogeography, and the evolution of web building behavior. Mol. Phylogenet. Evol. 38: 583-602.

Oliveira R.M., De Jesus A.C., Brescovit A.D. \& Cella D.M. 2007: Chromosomes of Crossopriza lyoni (Blackwall 1867), intraindividual numerical chromosome variation in Physocyclus globosus (Taczanowski 1874), and the distribution pattern of NORs (Araneomorphae, Haplogynae, Pholcidae). $J$. Arachnol. 35: 293-306.

Parida B.B., Mohanty P.K., Sahoo P. \& Mohapatra A. 1986: Studies on spermatocytic chromosomes of an aquatic wolf spider, Hippasa madhuae Tikader and Malhotra (Lycosidae: Araneae). Curr. Sci. 55: 997-998.

Peng Y., Hu C., Zhao J. \& Chen J. 1998: Karyotype analysis of Pirata piraticus (Araneae: Lycosidae). Acta Arachnol. Sin. 7: 142-145 [in Chinese, English abstr.].

Petrunkevitch A. 1928: Systema Aranearum. Trans. Connect. Acad. Arts Sci. 29: 1-270.

Platnick N.I. 2010: The World Spider Catalog. Version 11.0. American Museum of Natural History, online at http:// research.amnh.org/entomology/spiders/catalog/index.html.

Postiglioni A. \& Brum-Zorrilla N. 1981: Karyological studies on Uruguayan spiders II. Sex chromosomes in spiders of the genus Lycosa (Araneae - Lycosidae). Genetica 56: 47-53. 
Rodríguez-Gil S.G., Merani M.S., Scioscia C.L. \& Mola L.M. 2007: Cytogenetics in three species of Polybetes Simon 1879 from Argentina (Araneae, Sparassidae) I. Karyotype and chromosome banding pattern. J. Arachnol. 35: 227-237.

Rowell D.M. 1985: Complex sex-linked fusion heterozygosity in the Australian huntsman spider Delena cancerides (Araneae: Sparassidae). Chromosoma 93: 169-176.

Rowell D.M. 1990: Fixed fusion heterozygosity in Delena cancerides Walck. (Araneae: Sparassidae): an alternative to speciation by monobrachial fusion. Genetica 80: 139-157.

Sharma G.P., Jande S.S., Grewal M.S. \& Chopra R.N. 1958: Cytological studies on the Indian spiders. II. Chromosome complement and meiosis in seven species of the family Lycosidae. Res. Bull. Panjab Univ. 156: 255-269.

Simon E. 1937: Les Arachnides de France. Tome sixième (cinquième et dernière parte). Contenant le Synopis général et le Catalogue des espèces françaises de l'ordre des Aranece (suite et fin). Paris, pp. 979-1298 (published posthumously by L. Berland \& L. Fage).

SRIVASTAVA S.C. \& Shukla S. 1986: Chromosome number and sex determining mechanism in forty-seven species of Indian spiders. Chromos. Inform. Serv. 41:23-26.

SuMNER A.T. 1972: A simple technique for demonstrating centromeric heterochromatin. Exp. Cell. Res. 75: 304-306.

SuzUKI S. 1952: Cytological studies in spiders. II. Chromosomal investigation in the twenty two species of spiders belonging to the four families, Clubionidae, Sparassidae, Thomisidae and Oxyopidae, with constitute Clubionoidea, with special reference to sex chromosomes. J. Sci. Hiroshima Univ. (B) 13: $1-52$.

SuzuKI S. 1954: Cytological studies in spiders. III. Studies on the chromosomes of fifty-seven species of spiders belonging to seventeen families, with general considerations on chromosomal evolution. J. Sci. Hiroshima Univ. (B) 15: 23-136.

Traut W. 1976: Pachytene mapping in the female silkworm, Bombyx mori L. (Lepidoptera). Chromosoma 58: 275-284.

White M.J.D. 1973: Animal Cytology and Evolution. 3rd ed. Cambridge University Press, Cambridge, $961 \mathrm{pp}$.

WISE D. 1983: An electron microscope study of the karyotypes of two wolf spiders. Can. J. Genet. Cytol. 25: 161-168.

YANG Z., WANG X., WANG Y., CUI S. \& Hu H. 1996: On karyotype analysis of the Pardosa astrigera (Araneida: Lycosidae). Acta Arachnol. Sin. 5: 145-148 [in Chinese, English abstr.].

YANG Z., WANG X., WANG Y. \& CuI S. 1997: On the karyotype of Pirata piratoides (Araneae: Lycosidae). Acta Arachnol. Sin. 6: 23-25 [in Chinese, English abstr.].

Zyuzin A.A. 1985: Generic and subfamilial criteria in the systematics of the spider family Lycosidae (Aranei), with the description of a new genus and two new subfamilies. Proc. Zool. Inst. (Leningrad) 139: 40-51 [in Russian, English abstr.].

Received May 17, 2010; revised and accepted August 9, 2010 